\title{
Impact of Demographic Change upon the Sustainability of Fiscal Policy
}

\author{
Younggak Kim* \\ Myoung Chul Kim** \\ Seongyong $\mathrm{Im}^{* * *}$
}

The views expressed herein are those of authors and do not necessarily reflect the offcial views of the Bank of Korea. When reporting or citing this paper, the authors name should al ways be explicitly stated.

* Associate professor, School of Economics, Senshu University. E-mail : ykim@isc.senshu-u.ac.jp

** Economist, Monetary Policy \& Markets Department, Bank of Korea. E-mail : kimmc@bok.or.kr

*** Economist, Monetary Policy \& Markets Department, Bank of Korea. E-mail : imsy@bok.or.kr 


\section{Contents}

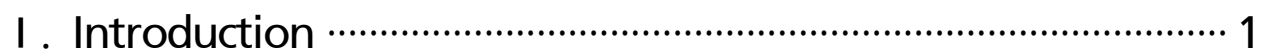

II. Literature Review ……................................................. 2

III. Finance of Japanese Government ……................................ 3

1 Expenditure and Revenue of Japanese government ……………….... 5

2 Change of Expenditure and Tax Revenue ……………………………. 8

3 Future Prospects …………………………………………………………... 10

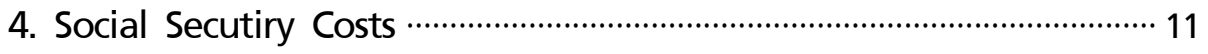

IV. Population and Japanese Government Finance …............. 15

1 Demographic Changes ………………………………………………….... 16

2 Demographic Changes and Social Security-related Expenditure … 19

3 Labor Force and Economic Growth …………………………………...... 22

V. The Long Run Korean Government's Fiscal Conditions * 25

1 The Korean Demographic Structure …………………………………... 25

2 Evaluating the Sustainability of Korean Long-term Fiscal Policy $\cdots 26$

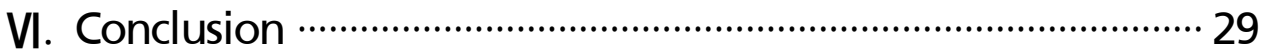

<Appendix> The Methodology of Generational Accounting * 31

$<$ References $>$ 


\section{Impact of Demographic Change upon the Sustainability of Fiscal Policy}

This paper analyzes the impact of demographic change on the sustainability of fiscal policy. Firstly, we study the main causes of the deterioration of J apanese government fiscal conditions from the demographic point of view. Next, we investigate the impact of Korean population aging on the long-term fiscal conditions using the method of the forward looking measure of Generational Accounting.

Most of the deterioration in the fiscal situation of the J apanese government since 1990 can be explained by an increase in social security costs related with population aging and a decrease in tax revenue caused by lackluster economy. Considering the rapid population aging, Korean government's fiscal condition, evaluated to be very sound currently, could also deteriorate soon without counteracting preemptively. The results of Korean Generational Accounting show that the sodal security related expenditures are main drives for the deterioration of long-term fiscal condition. In addition, as shown by the case of J apan, the effect of the decreased tax revenue could be greater than that of increased expenditure. The policy for improving the tax revenue through economic growth is also very important for the sustainability of government finance.

Keywords: Demographic structure, Generational Accounting, Social security costs

JEL Classification: E24, H50, J 10 


\section{Introduction}

Changes in the demographic structure such as the rapid increase in the share of the aged population have brought various challenges to our economy. According to the Korea National Statistics, Korea is entering into an aged society very rapidly, the share of population aged 65 years or older is estimated to be $12.2 \%$ in 2013 . The ratio is expected to $14.5 \%$, which means entering into the aged society, in 2018 and to reach $20.8 \%$ in 2026 , to become super-aged. One of the key issues, related with population aging, is the lowering of the long-term growth rate. The increase in the share of old age group means the decrease in the share of working age group. This is going to devitalize the national economy. The effect goes through the economy and brings many long-term issues as well. Many previous studies have said that the demographic transition will have a great influence on the long-term sustainability of fiscal policies.1) For example, if current system is provided regarding major public pensions and health insurance fund, tremendous fiscal pressure will be put on the future generation.

Japan's experiences for the last 10 or 20 years have provided many lessons about the impacts of demographic change on the macroeconomic performance. Specially, Japan's high government debt as a percentage of GDP which is over $200 \%$ has received great attention recently. Considering the rapid population aging in Korea, studying the main causes of the deterioration of J apanese government fiscal conditions from the demographic point of view will give us an important guideline for Korean future fiscal policy operation.

The paper is organized as follows. In section 2, we briefly review the literature for studying evaluation of long-term fiscal sustainability. In section 3 and 4, we will have chance to study the implications of demographic changes on economy and financial conditions through a J apanese case. Section 3 overviews the financial status of J apanese government, and try to figure out the main cause of the deterioration of the financial condition. Section 4 overviews the demographic changes in J apan, and stands on the demographic viewpoint to analyze whether and how much impact the population change had on the government finance in detail. Section 5

1) See Hyung-soo Park and Seung Hyun Hong (2011), Alison Felix and Kate Watkins (2013), Alan J. Auerbach (2012), etc. for further detail. 
compares the demographic developments of J apan and Korea, and checks the long run risk factors for Korean government fiscal conditions by using the method of Generational Accounting2). Section 6 condudes the paper.

\section{Literature Review}

Many methods have been developed to evaluate fiscal sustainability such as baseline projection, balance sheet analysis, fiscal gap analysis, and Generational Accounting.

First, the baseline projection method is used by the US Congressional Budget Office to evaluate fiscal sustainability. This is used to forecast future budget conditions under the condition that there is no change in government fiscal course (A. Schick, 2005). This method has merit in terms of enabling us to evaluate future fiscal condition and providing us with measures to estimate the policy effectiveness. However, future forecast is grounded just on limited variable such as inflation rate and economic growth it could not represent complex real economic situations.

Second, balance sheet analysis evaluates fiscal sustainability centering on stock data. While budget analysis indudes only flow data such as revenue and expenditure, balance sheet provides all asset and liability regardless of its maturity. Balance sheet analysis, however, has a shortcoming in that it recognizes only current liabilities and does not indude potential debt. So it could underestimate fiscal conditions.

Third, fiscal gap analysis used by Kotlikoff and Burns (2004) assesses fiscal sustainability using a gap between a targeted debt level and the debt that would ensue if policies were continued without changes to a specific point of time. This method is future oriented and dynamic as it enables us to set a target debt level to nominal GDP ratio based on multiple forecasts. Nevertheless, measuring feasibility of policy is only possible after policy implementation.

2) Generational Accounting, introduced in 1991 by economists Alan Auerbach, Jagadeesh Gokhale, and Laurence Kotlikoff, is used to eval uate long-term fiscal sustainability and fiscal burdens of current and future generations depending on long-term prospects. 
Fourth, Generational Accounting provides another method of evaluating sustainabilitiy of fiscal policy (Auerbach, Gokhale, and Kotlikoff: A-G-K, 1991). Generational Accounting, through long-term fiscal forecast, estimates fiscal burden of future generation and we can evaluate government fiscal condition through this result. This method is simple and intuitive to assess future fiscal sustainability. Generational Accounting is useful in examining the effect of entitlement programs such as national pension considering demographic change.

Auerbach et al. (1999) in "Generational Accounting around the world" shows the result of Generational Accounting of major advanced countries. Many central banks such as the US, Japan, Netherland, and I taly also have already used Generational Accounting respectively to assess fiscal situations. In Korea, as concern about long-term fiscal sustainability increases, Auerbach and Chun (2006), Auerbach, Chun, and Yoo (2005), Choi (2013) use this method to evaluate fiscal conditions and national pension sustainability. However, in the following points, Korean Generational Accounting needs to be discussed further. First, we should update the micro data (relative profile), which is required to forecast revenue and expenditure of future government, as there have been institutional changes3) in pensions. Second, we indude public enterprise sector in order to measure the government's burden on public enterprises which was not induded previously.

\section{Finance of J apanese Government}

According to Doi (2009), Shirakawa (2010), and Fukao (2012), under the reasonable assumption, it takes a $30 \%$ point increase of the consumption tax or long-term reconstruction plan lasting at least for 100 years to restore the sustainability of the J apanese government finance. J apanese government has a plan to enhance the consumption tax up to $10 \%$ in 2015 . Yet the reform is far from being enough. Some alarms the possibility of a sharp increase in the interest rate of government bond and drastic drop in exchange rate resulting from the unsustain-

3) For example, National Pension Service publishes new "Actuarial Projection Result" in J une 2013. And Civil Servants Pension newly introduced inaugural age, 65 of receiving pension services in 2010. 
ability of the government finance. For now, none of the symptoms is observed and the possibility of the price collapse of the J apanese government bond seems very low. However, such a huge debt is never good in many aspects for the Japanese economy.

The history of the huge government debt in J apan is not so long. While the ratio of government bond outstanding to GDP in 1997 was about 55\%, it is around $150 \%$ at the end of 2013. Many researchers investigated what caused such a long-lasting huge finandial deficit. Some of them are such as extended fiscal policy and slow-down of the economic growth. Before discussing the finance of J apanese government in detail, it is useful to overview the time line of the J apanese economy after the end of World War II. Post-war period is, in general, divided into the four, restoration period, rapid growth period, stable growth period, and the lost decades. Between the periods, there is some dear differences in terms of economic situation.

J ust after the World War II, J apanese economy experienced severe shortage of goods and materials and hyperinflation. However, the Korean War served as an economic recovery momentum. The war increased the demand, so that the J apanese economy turned the corner to the period of the rapid economic growth, enjoying $9.1 \%$ growth rate on average over the following 20 years, mid-1950s to mid-1970s. With the transition to the floating exchange rate system and the oil shock resulting from fourth Middle East War, J apanese economy turned to the stable growth period. It enjoyed the $4.2 \%$ annual growth of the economy on average following 10 years. However, in the second half of 1980s, bubble economy was formed and busted in 1991, resulting huge negative economic shocks. Since then the economy fell into the pit of the lost decade (or decades). From 1991 to 2001, the average growth rate of nominal GDP was $0 \%$ Figure 1 plots the nominal GDP from 1955, giving the overall look on the Japanese economy for the period. 
Figure1. GDP and growth rate

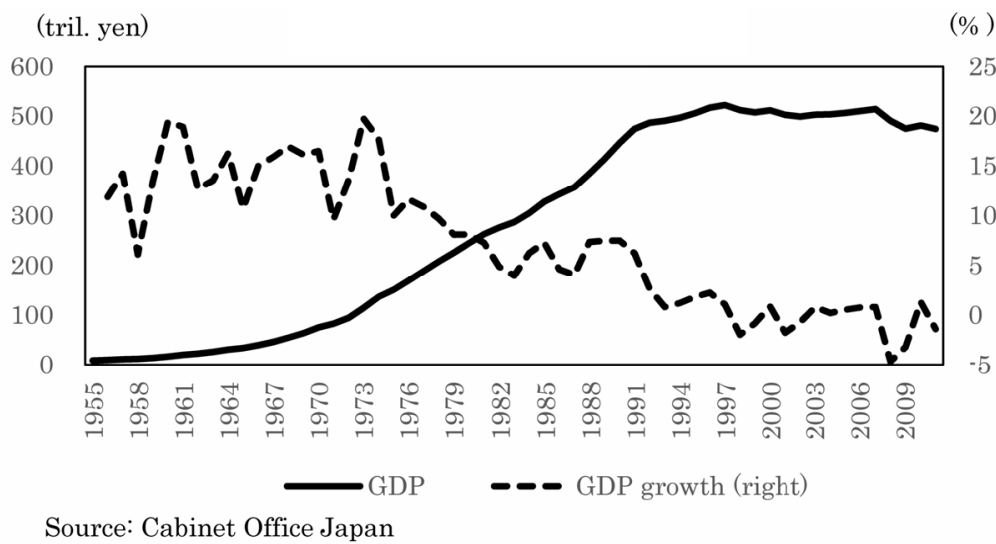

\section{Expenditure and Revenue of J apanese Government}

Figure 2 shows the major items of general accounts of J apanese government in 2012. In the expenditure side, $30 \%$ are social security cost, $22 \%$ are for the national debt service, and $17 \%$ are for local allocation tax grant, summing up to $70 \%$ of the whole expenditure. The percentage of the three major expenditure items in 2013 is expected to grow to 31\%, 24\%, and 18\%, respectively, sum of which is greater than that in 2012. Figure 2-b shows that tax revenue accounts for $41 \%$ and public debt revenue accounts for $46 \%$ of the whole revenue in 2012 , which is much different from the case of other OECD countries where the major part of the revenue is tax.

Figure2-a. General Accounts

(Expenditure)

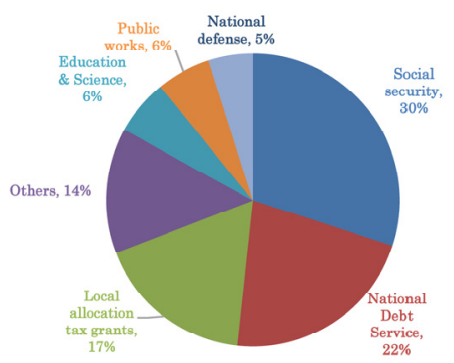

Source: Ministry of Finance Japan
Figure2-b. General Accounts (Revenue)

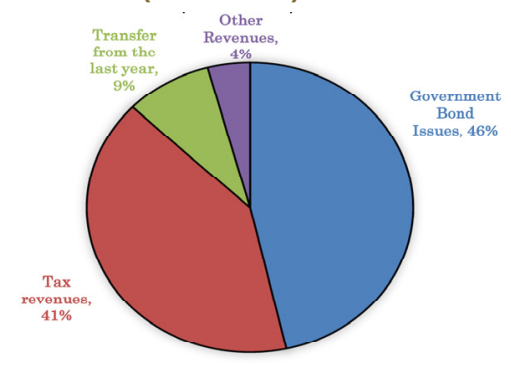

Source: Ministry of Finance Japan 
Figure 3. Government Bond Outstanding

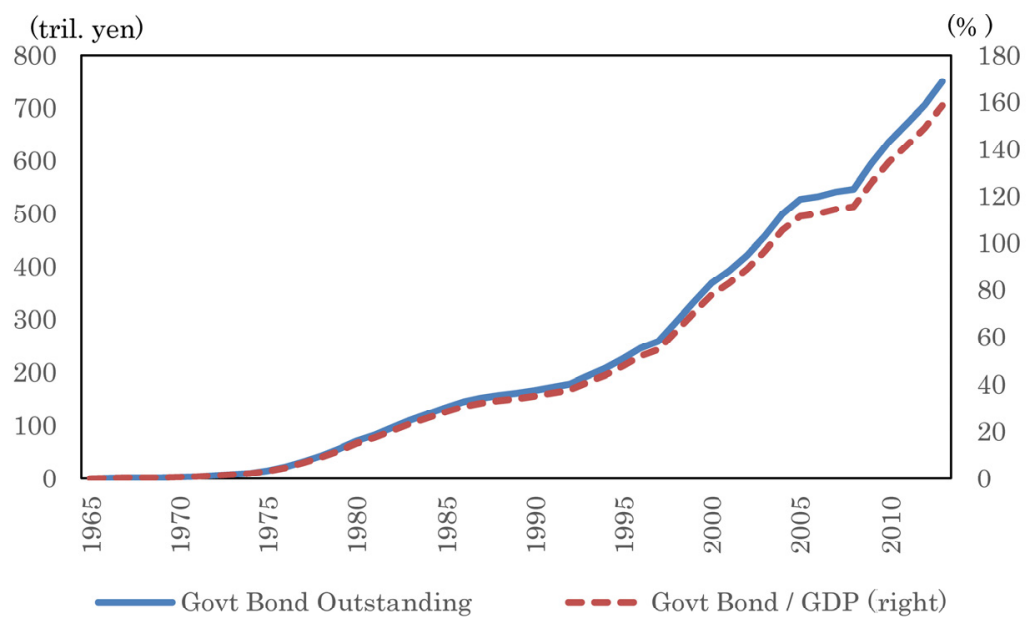

Source: Ministry of Finance Japan

The deficit in the primary balance in 2012 (budget base) is more than 20 trillion yen in the initial budget basis general accounting; it amounts to about $25 \%$ of the budget scale. The primary budget balance of 2013 general account is expected to be further deteriorated. The financial situation of the J apanese government in recent years is very poor.

Since the sustained large-scale budget deficit has been financed by issuing government bonds, public debt has been accumulated to a very high level. The accumulated government bond dearly reflects the seriousness of the financial situation that the J apanese government is currently facing. Figure 3 presents the changes of the government bonds outstanding for 1965 to 2013. It exceeded 50\% of GDP in 1996, then, kept increasing rapidly after then, reaching up to $150 \%$ of GDP at the end of 2012.

What made the financial situation of J apanese government so bad is continuing deficit. It may result from increasing expenditure or decreasing revenues, or both. To figure out which is the case, Figure 4 plots the changes of the expenditures and revenues of the general accounts. As seen dearly, the deficit began to grow rapidly after 1990, and it results from both of increasing expenditure and decreasing 
revenue. Therefore to fill up the gap, government bond has been issued, and its balance dimbed up with higher speed than ever.

Figure 3 shows that the ratio of the outstanding of the government bond to GDP stays 35\% in 1990, which is not much higher than that in 1985 (28\%). The tax revenue grew faster than expenditure before 1990, so that the government bond balance lowered in the period, and by and large the government finance was balanced in 1990. Therefore the present government debt has been formed by the excess expenditure and shortage of revenue after late 1990s.

Now, the paper checks how much a decrease in tax revenues and an increase in expenditures contributed to the increase in the balance of outstanding government bonds based on the 1990, and what made such gap continuing after 1990. To see more dosely, the paper considers separately the two items in the next section.

Figure 4. Government Expenditure and Tax Revenue

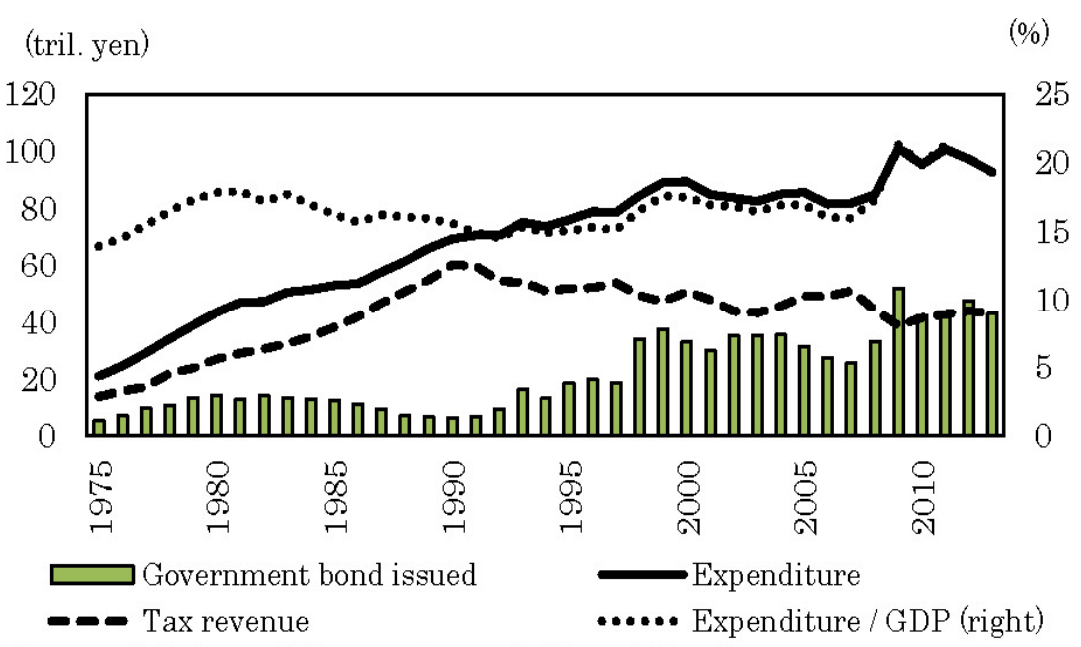

Sources: Ministry of Finance Japan, Cabinet Office Japan 
Figure 5. Expenditure of General Accounts

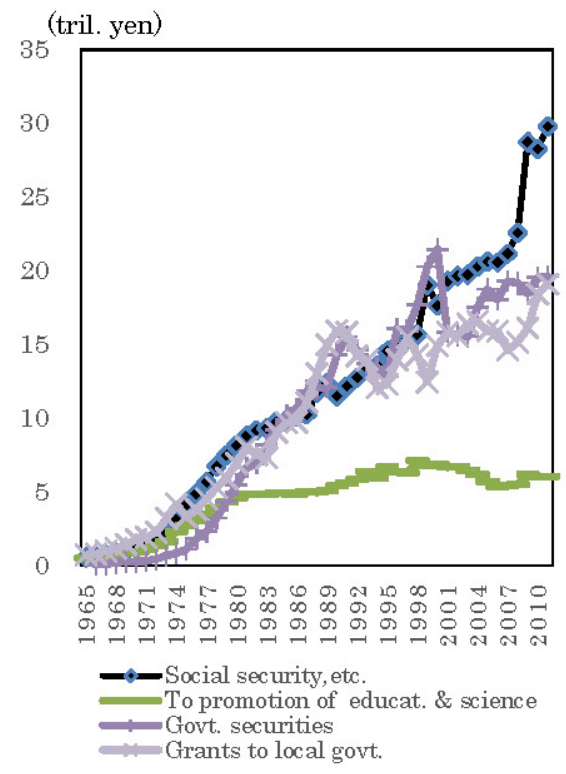

Source: Ministry of Finance Japan
Figure 6. Revenue of General Accounts

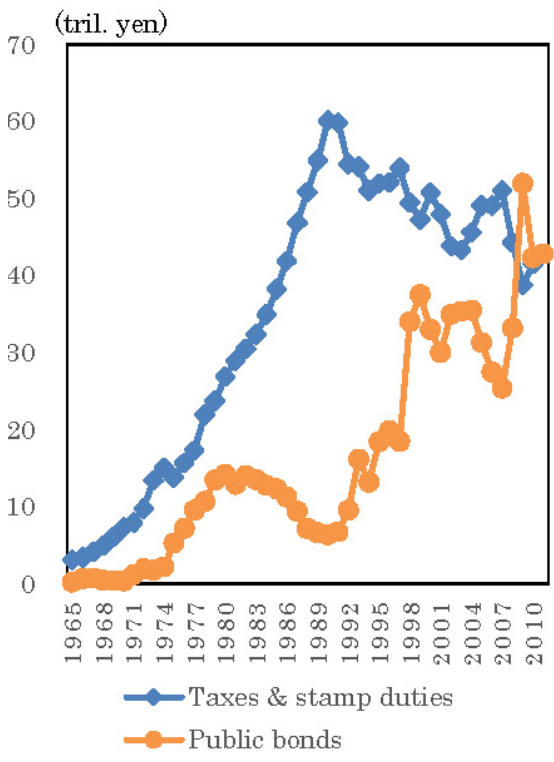

Source: Ministry of Finance Japan

\section{Change of Expenditure and Tax Revenue}

Figures 5 and 6 present the changes of the main items of revenues and expenditures of the general accounts from 1963 to 2011. Just after tax revenue peaked in 1990, government bond issues have surged. Government bond issues are greater than the tax revenue after 2009 in particular.

There are three major expenditure items of the general accounts which have been increasing since 1990, that is, expenditures for social security, for national debt service, and for local allocations tax grants. Figures 7 and 8 calculate and show how much expenditures and revenues have changed after 1990 based on the expenditures and revenues in 1990. The increase (decrease) of each expenditure or revenue item is accumulated compared with each value in 1990. The accumulated local allocations tax grants after 1990 is - 16 trillion yen, which do not contribute much to the accumulation of the government debt. Greatest contributor to the accumulated expenditure compared to that in 1990 is expenditures for social security which amounts up to 194 trillion yen. If induding the expenditures for pro- 
motion of education and science and local allocation tax grants, the accumulated expenditure compared to those in 1990 amounts up to 197 trillion yen, which shows that most part of the increased government debt in expenditure side compared to that in 1990 is expenditure for social security.

Tax revenue has monotonically decreased after 1990, so accumulated decrease in tax revenue is 275 trillion yen. Since the accumulated increase of major expenditures after 1990 is 197 trillion yen, the accumulated deficit in major parts of the general account of J apanese government since 1990 is 472 trillion yen. In other words, based on the general accounts in 1990, 58\% of the accumulated deficit are caused by the decrease of the tax revenue, and remaining $42 \%$ by the increase of the expenditure, especially for the social security. The accumulated deficit cal culated here is about $81 \%$ of the increase of the government debt from 1990 to 2013, that is, 584 trillion yen. To sum up, most of the deterioration in the fiscal situation of the Japanese government since 1990 can be explained by a decrease in tax revenue and the increase in social security costs.

Figure 7. Increase of Expenditure, General Accounts (Compared with those in 1990)

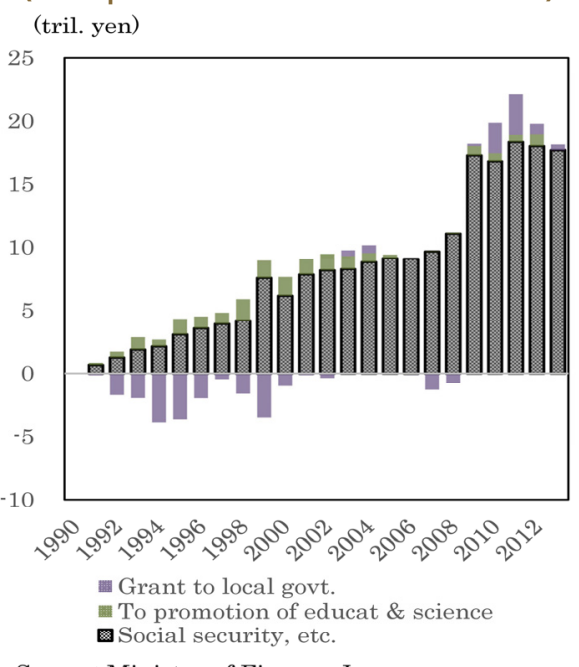

Source: Ministry of Finance Japan
Figure 8. Decrease of Taxes \& Stamp Duties (Compared with those in 1990)

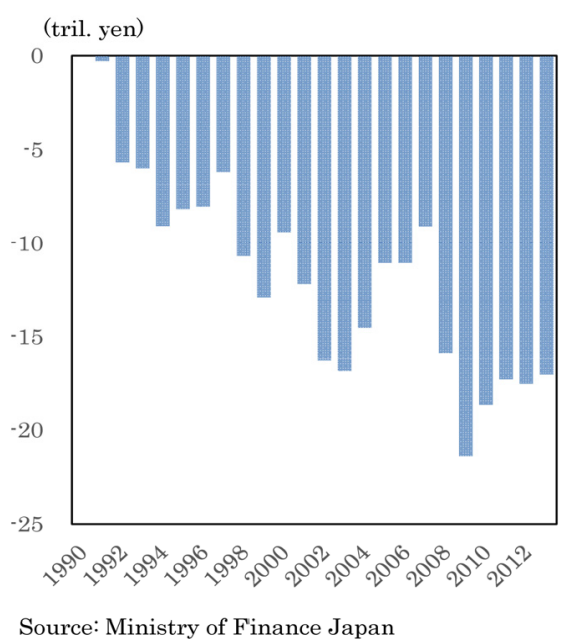

Source: Ministry of Finance Japan 


\section{Future Prospects}

Primary balance is most often-used index to check how sound the long-term financial condition is. Figure 9 shows the change in the primary balance as a percentage of GDP. After the deterioration in 1970s by the oil shock, it got better soon to be the surplus of $1.2 \%$ of GDP in the late 1980s. In 1990s, however, it turned to deficit rapidly thereafter. After the short improvement of the primary balance in the boom from 2003 to 2007, it turns to getting worse again after the, so-called, Lehman shock.

J apanese Cabinet Office announced the predicted value of the primary balance in the future (Cabinet Office, 2013). It assumes that improvement of general accounting proceed along the medium-term financial planning, that consumption tax is raised to 8\% in April 2014 as scheduled, and to 10\% in October 2015, and that annual growth rate of the economy in real term is $2 \%$, (that is $3 \%$ annual growth rate in nominal term) is achieved in the coming years as Abenomics currently assumes.

Under such hopeful assumptions, primary balance is predicted to improve to be deficit of $2 \%$ of GDP in 2020, which means that the government debt will keep increasing in the coming 10 or 20 years. However, when assuming 1\% annual growth in real term, (that is $2 \%$ annual growth rate in nominal term) because the assumption of growth rate is higher than the real growth rate in recent years, a deficit of

Figure 9. Primary Balance / GDP

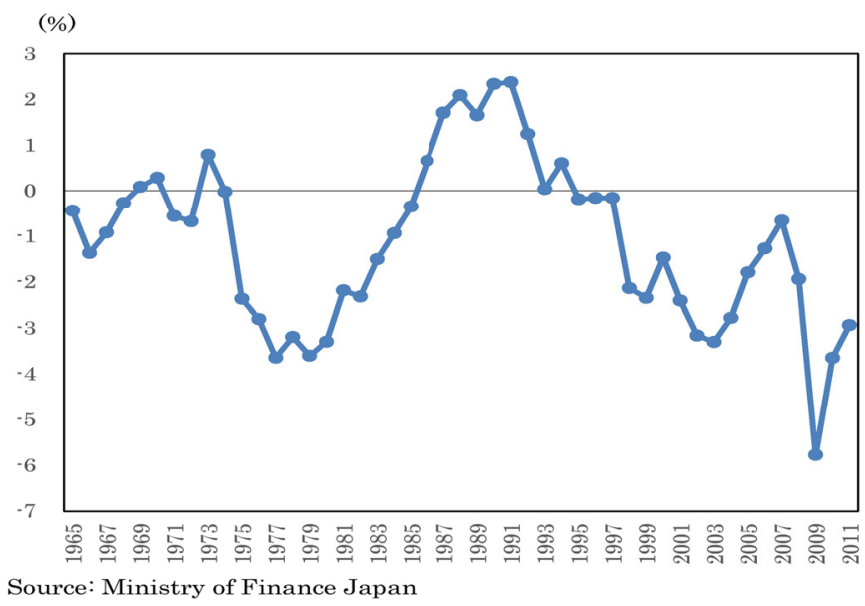


more than 3\% of GDP in primary balance is expected in fiscal 2020. In sum, under the realistic assumptions, government debt never decreases in the near future.

One may insist that the increases of government debt in 1998, 2002, 2009, and 2011 are temporary and do not last so long, because they are caused by the Asian finandial crisis, Lehman shock, and 3.11 Tohoku earthquake and tsunami, which cannot be forecast nor prepared for. However, the calculation of the Cabinet Office shows that the primary balance, not the general account, will continue to be in deficit in the future, resulting in increasing government debt.

The paper discusses on the social security and economic growth in the following section, because they are the most important factors causing the deficit in the government balance.

\section{Social Security Costs}

As described above, it is dear that the main cause of the deterioration of the fiscal condition in recent years is the social security expenses, which is confirmed in Figure 5. Figure 10 plots the changes of the share of the each expenditure among the total expenditures in general accounts in each year. Most prominent change between 1965 and 2011 is those of social security. Social security payment raises its shares from about $21 \%$ to $37 \%$ between 1990 and 2011 . Figure 11 plots the changes of the ratio of individual expenditure over GDP. While the ratio of the expenditures for the education and science and grants to local government do not rise after 1990, but that of social security payment has surged especially after 1999. It was $4.6 \%$ in 2008 , but rose up to $6.3 \%$ in 2011 . In early 1990 s, the ratio lowered to $2.6 \%$ for a moment because of the high growth rate of GDP rather than the slowdown of expenditure for the social security (in Figure 5). The ratio of the social security over GDP is mostly stable in 1990s until 1998. The period has been called "the lost decade." If the increase in social security payment in 1990s were mainly for the unemployment 4 ) and other social security policy to counteract the economic recession, the ratio of the social security over GDP in Figure 11 should have surged in 1990s. However, it did not in 1990s, but did surge in 2000s. Figures

4) The employment ratio in 1990 s did go up from $2 \%$ to $4 \%$ 
5,10 , and 11 imply that the increase in the expenditure for the social security in recent years is not because of the prolonged recessions, but because of other structural cause.

Figure 10. Share of Expenditures Figure 11. Govt Expenditure / GDP

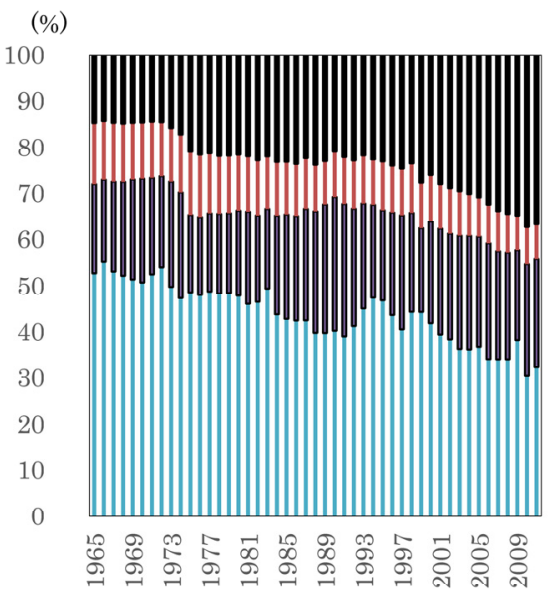

- Social security, etc.

To promotion of educat. \& science

$\square$ Grant to local govt.

nothers

Source: Ministry of Finance Japan
(\%)

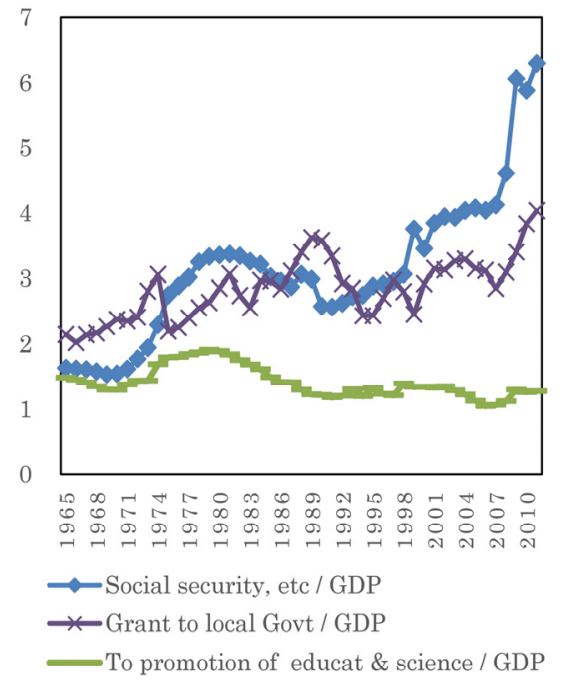

Source: Ministry of Finance Japan

Figure 12. Social Security-related Expenditures

(General account)

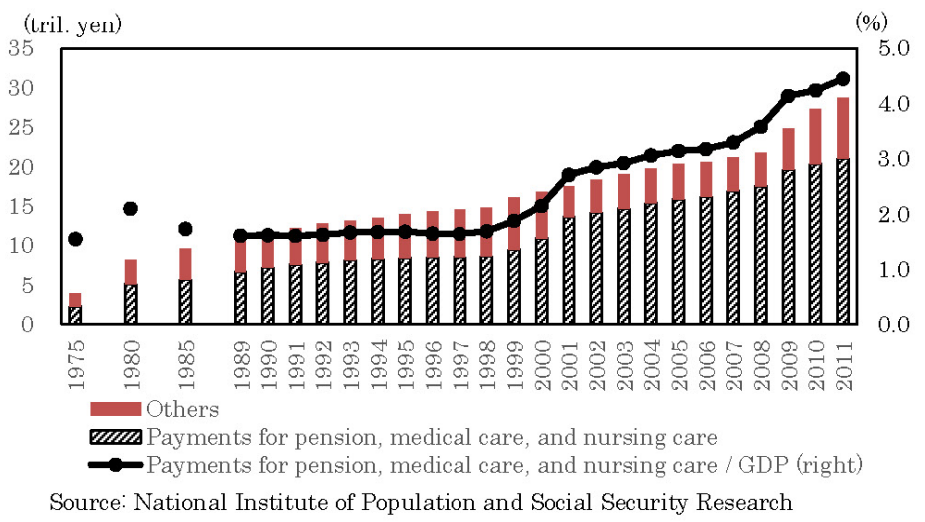


To make dear what pushes up the expenditures for sodial security, Figure 12 breaks up the sodial security payment in the general accounts of each year. The expenditures for social seaurity consist of payments for pension, medical care, nursing care, livelihood protection, social welfare, hygiene, and employment policy, and others. In the budget, payments for pension, medical care, and nursing care are categorized into one, and it is about $70 \%$ of the total social security-related expenditures. Figure 12 shows the payments for pension, medical care, and nursing care, and other social security-related expenditures from 1967 to 2011.5) While the share of the payments for pension, medical care, and nursing care was about 59\% of the total social security-related expenditures in 1975, it is 73\% in 2011. Other social security-related payments, on the contrary, dedine in 2000s. Figure 12 also depicts the ratio of the payments for pension, medical care, and nursing care over GDP to see whether the background for its increase is the normal economic growth. Figure 12 shows the payments for these services and GDP rose with the similar speed in 1990s, but the former has grown up faster than the latter in 2000s so that the ratio grows up from $1.7 \%$ in 1990 s to $4.4 \%$ in 2011 . Summing up, the increase of the social security-related expenditure is mainly attributable to the increase of the payments for pension, medical care, and nursing care.

\section{Figure 13. Social Insurance Revenue and Benefits Costs}

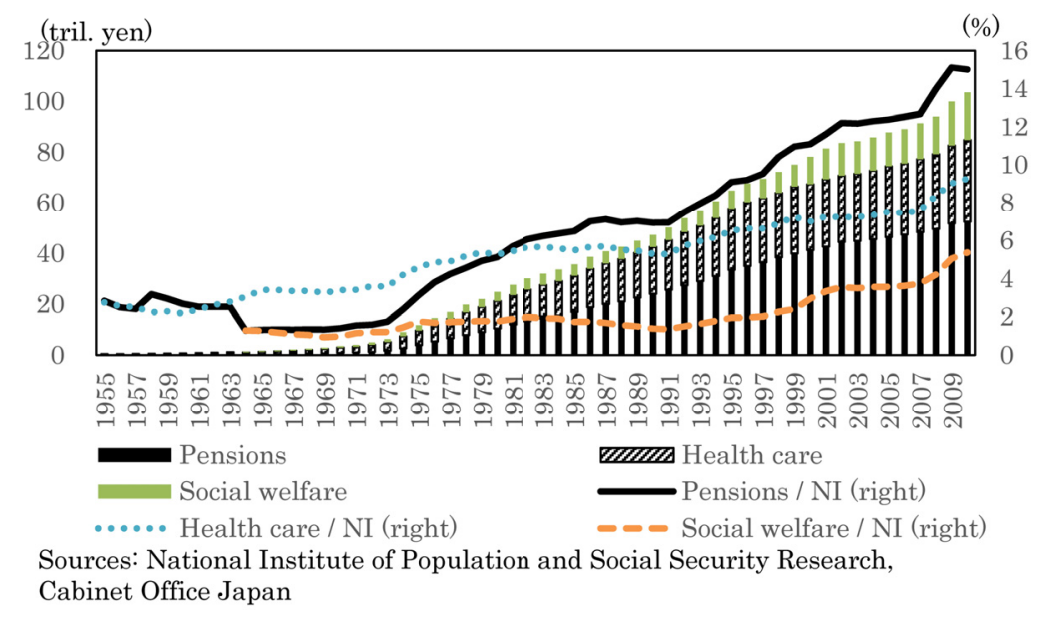

5) Some concepts in the survey are changed in 2009, so that there isa jump between 2008 and 2009 in the statistics. 
Why, then, the payments for pension, medical care, and nursing care rose so much in recent years? In order to figure out the reason, it is useful to understand the structure of the welfare benefit cost, because the payments for pension, medical care, and nursing care is only a part of the total welfare benefit cost. The total welfare benefit cost in 2013 budget is about 110.6 trillion yen (100\%), and 53.5 trillion yen $(48.4 \%)$ is paid for pension, 36.0 trillion yen (32.5\%) is for medical care, and 21.1 trillion yen (19.1\%) for long-term care and welfare. Although it is financed by mainly insurance premium (62.2 trillion yen, 56\%), remaining part is financed by the national tax transfer (29.7 trillion yen, 27\%) and local tax transfer (11.2 trillion yen, 10\%). Figure 13 shows the changes of welfare benefit cost and its insurance premium revenue. While the total welfare cost has monotonically risen up to over than 100 trillion yen in the late 2000s, its insurance premium revenue stopped its increasing trend around 1995. GDP in the same figure shows that the kink of the insurance premium revenue might be caused by the economic slump in late 1990s and 2000s. Since the gap between revenue and the benefit cost is filled up by the tax transfer of the national and local government, social security-related expenditure in the general account of the government is pushed up. Welfare benefit cost monotonically increased from 1970s, and faster in 1990s than in 1980s.

\section{Figure 14. Welfare Benefit}

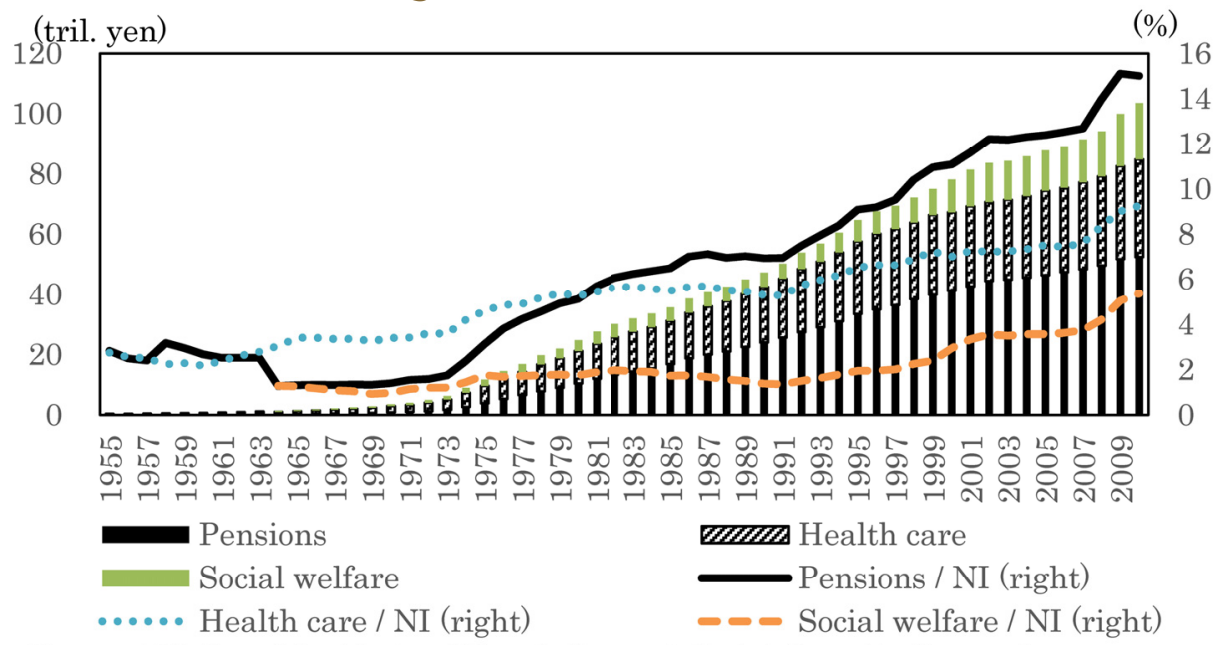

Sources: National Institute of Population and Social Security Research,

Cabinet Office Japan 
Main parts of the welfare benefit are medical care, pension and other welfare costs. The total welfare benefit of 103 trillion yen in 2010, for example, is paid for medical care (32 trillion yen, 31\%), for pension (51 trillion yen, 51\%), and other welfare (19 trillion yen, 18\%). Figure 14 shows the structure and changes of the welfare benefit from 1975 to 2010 . The figure shows that the welfare benefit has increased by 2.6 trillion yen every year, and is increasing even now. While the share of pension rose in 1970s and 1980s, but that of other welfare cost increased in 2000s. The figure also depicts the ratio of the three costs over National I ncome, showing that all the ratios rose up significantly after 1990 and their increasing trend lasts until recent years. The ratio of the pension doubled from $6.9 \%$ in 1990 to $15.0 \%$ in 2010 , and that of other welfare cost almost quadrupled in the sample period from $1.4 \%$ to $5.4 \%$ Comparing with them, medical care benefit grew milder from $5.3 \%$ to $9.3 \%$ between 1990 and 2010 . The total welfare benefit rose by 5.6 billion yen, and the increase is attributable to the pension by $50 \%$ ( 28 trillion yen) and to the other two benefits by $25 \%$ ( 14 trillion yen) respectively.

One may conjecture that the increase of the welfare benefit above is caused by the change of the demographic structure. Low birth rate and aging may result in increase of the medical care and pension. It is reported that total cost of the medical care was 37.5 trillion yen in 2010, and 20.7 trillion yen (55\%) was paid for the service for the elderly. The share of the elderly was $23 \%$ in the year. As described above, other welfare benefit increased fastest after 1990 among the three. The benefit for other social welfare was 18.7 trillion yen in 2010, and 7.3 trillion yen was paid for the nursing care, which is closely related with the elderly. In the following section, the paper discusses on the change of the population.

\section{Population and J apanese Government Finance}

It was discussed that the two main sources of the deterioration of the financial condition of J apanese government were the increase of the social security-related expenditures and substantial decrease of tax revenue. The surge of the social security-related expenditures in the general account is attributable to the increase of the payments for pension, medical care, and nursing care. Such increase was generated by the gap between the welfare benefit and insurance premium revenue, because the gap is financed by the social security-related expenditure in 
Figure 15. Population

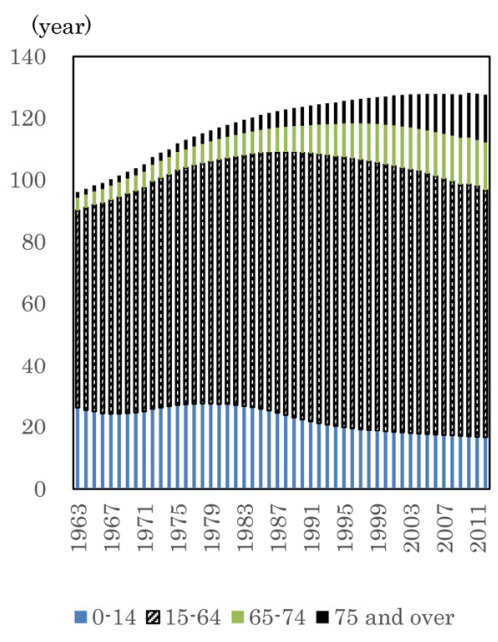

Source: National Institute of Population and Social Security Research Japan
Figure 16. Live Birthes and Fertility Rate

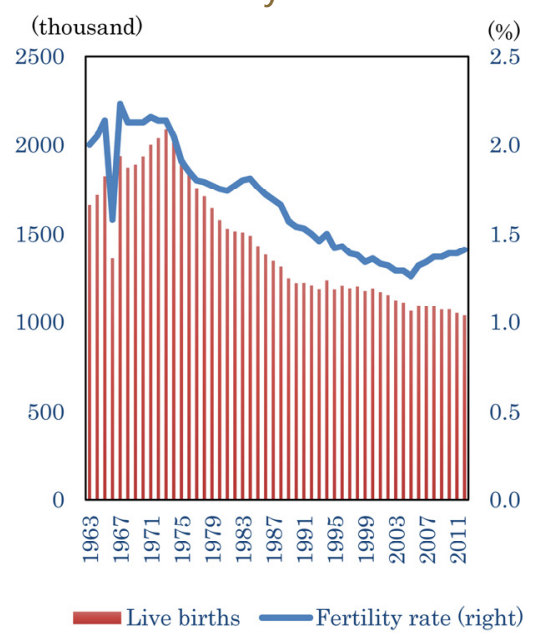

Source: Ministry of Health, Labour and Welfare Japan

the general account. The major parts of the welfare benefit are pension, medical care, and other social welfare service (induding nursing care). Meanwhile the decreases of the tax revenue account for the accumulated government debt.

These factors are supposed to be related with the demographic changes. This section will discuss on the topics above from the demographic point of view.

\section{Demographic Changes}

We give an overview of the demographic structure and its transition over time in this section. Figure 15 shows the total population and its four age groups, 0-14 year old, 15-64 year old, 65-75 year old, and 75 and over, between 1963 and 2013. The population grows at over than $1 \%$ annual growth rate until mid-1970s, the growth rate lowered gradually in 1980s through 2000s, and began to decrease in 2008. Overall, it is very dear and impressive that the population grows older gradually and steadily.

Young age group (0-14) has steadily dropped not only its share but also its number itself from 1979 because of the decrease in the number of live birth. Figure 16 plots the number of live birth and fertility rate. It is noteworthy that not only the number of the live birth but also the fertility rate began to drop in 1973. 
In the long-term, J apanese society had two baby-boomer groups, who were born in 1947-1949 and 1971-1973. The baby boom depicted in Figure 16 is the second one. After the second baby boom, the number of live birth dropped and the fertility rate lowered down under 2 from 1975, and now it was 1.41 in 2012.

Another impressive point in Figure 15 is the gradual increase of the elderly. In Japan where labor scarcely moves internationally, increase of the population is solely attributable to the extension of the life. Figure 17 depicts the remaining life expectancy according to the age group in each year. Life expectancy of 0 year old age group is generally used for the international comparison.

Comparing the values in 2011 with those in 1950, the expectancies of every age group are greatly extended. The life expectancy of the 0 year old group is extended by about 20 years between 1950 and 2011. For 70 year old male group, it is extended by about 6 years, whereas female group, 9 years. The life expectancy was extended even in 1990s and 2000s by 2.3 years for 70 year old male group and by 3.4 years for 70 year old female group. Most of J apan's social security schemes were established in 1960s and 1970s, so that such systems were not designed to take into full account such extensions of the life expectancy. As a result, the share of the elderly in the economy naturally increased. Figure 18 depicts the changes of the share of each age group in the total population, showing that the share of 75 and over year old group rose fast and were about 12\% in 2012 which is al most same to the share of 65-74 year old group in that year.

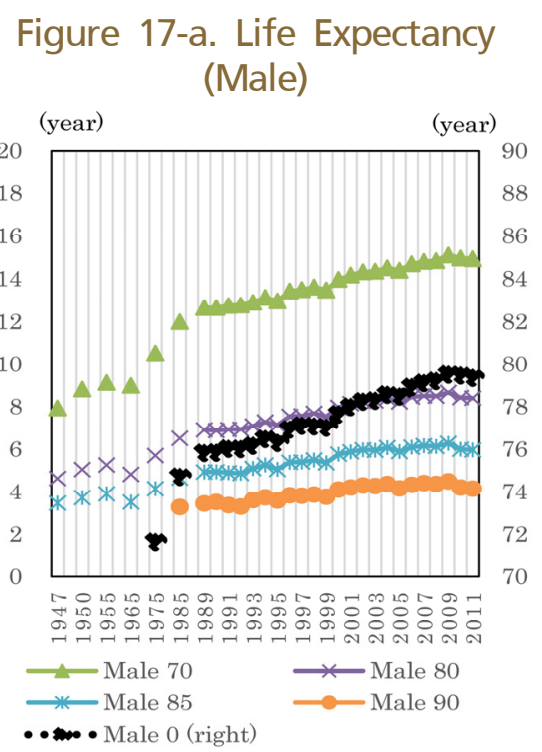

Source: Ministry of Health, Labour and Welfare Japan
Figure 17-b. Life Expectancy (Female)

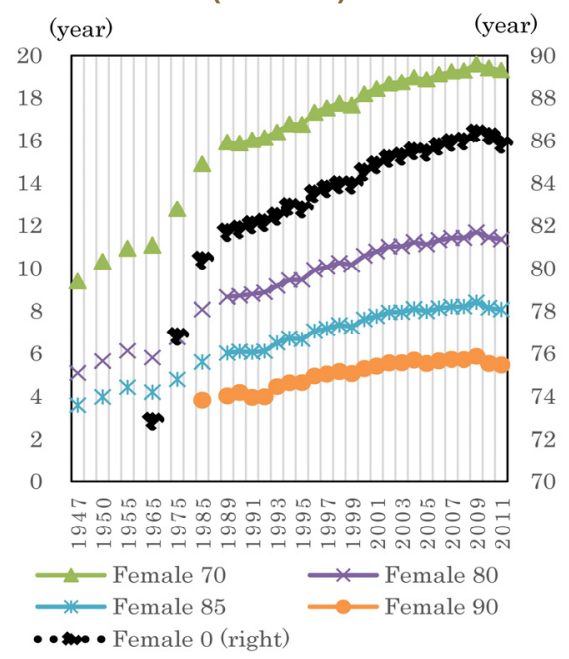

Source: Ministry of Health, Labour and Welfare Japan 
15-64 year old group had two peaks in Figure 18, one in late 1960s, and another in late 1980s. They are because the post-war baby-boomers born in 1947-1949 or 1971-1973 got into the age group. After the second peak, the age group dropped both of their number and share in J apan. The drops of the share of 15-64 year old group and rise of the elderly began almost simultaneously from 1990. This change means that the structural change of the social security is taking place. The ratio of the number of people in 15-64 year old group over that of the elderly (65 and over year old), which basically imply how many economically active people supports 1 elderly person, was more than 9 in the fast-growing period, whereas it is just 2.6 in 2012, implying that less than 3 persons should support one elderly today. According to the forecast provided by the National institute of population and social security research, the ratio will be less than 2 in 2025 .

These numbers and changes imply that present social seaurity scheme is not sustainable. Although Japanese government reformed the schemes several times after the establishment in 1960s with reasonably appearing anticipations, revised system could not fully deal with such gradual changes in population. Both of the dedines in birth rate and extensions of the life expectancy were much greater than the anticipation.

\section{Figure 18. Share of Age Group}

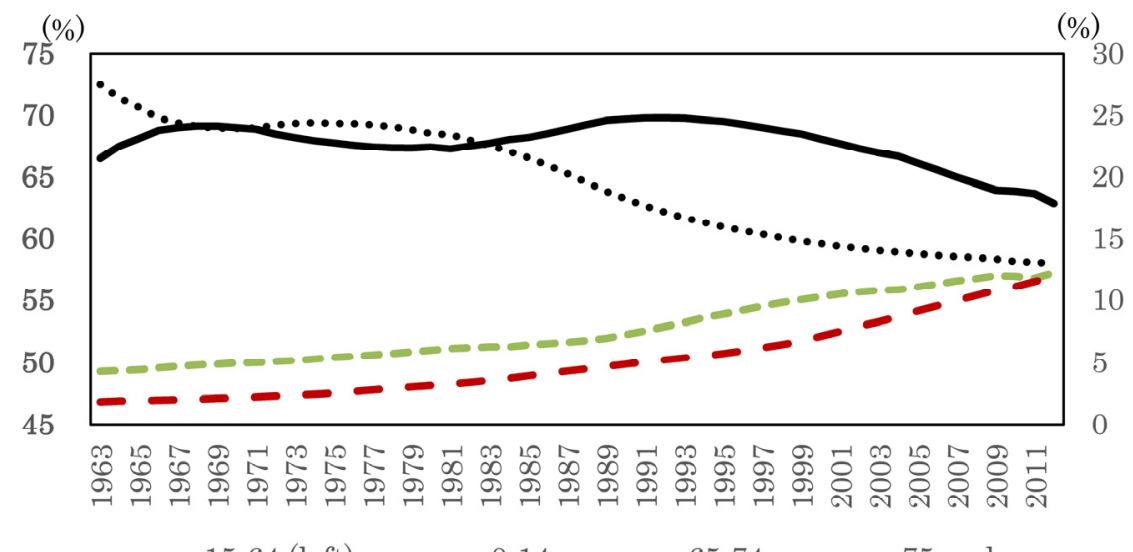

Source: National Institute of Population and Social Security Research 


\section{Demographic Changes and Social Security-related Expenditure}

As described above, the social security system was introduced and established in 1960s and 1970s; the universal coverage of pensions and health insurance were introduced in 1961. After the multiple revisions of such system, they established foundation in 1970. As seen in Figure 16, birth rate in 1970 was over than 2, and J apanese government (and any other) could not anticipate such a low level of birth rate and extended life span.

We now discuss on pension, medical care, and nursing care in this section to observe what effects the demographic changes had on the increase of the welfare benefit cost.

\subsection{Pensions}

Pension system is usually operated by either one of the two, funded or pay-as-you-go scheme. J apanese pension system was originally designed by funded scheme, and revised and operated by the, so-called, revised funded scheme. However, with the introduction of the basic pension system in 1985, intergenerational support system was strengthened after then. Now the pension system is very dose to the pay-as-you-go scheme. Since insurance premium revenue of the present working generation is used for the pension benefit, intergenerational inequality in their benefit and burden is more likely to increase. Suzuki et al. (2012) showed that people born before 1955 receive more benefit than their life time burden, and people born after 1955 receive less. People born in 1950 receive, for example, 5 million yen more than their burden. But people born in 1985 pays 7 million yen more than the benefit they expect to receive. The expected gap between the benefit and burden for the people born in 2010 is 5 million yen.

Returning to Figure 14, which shows the changes of the social security-related expenditures and the ratio of them over National income (NI) in the general account between 1975 and 2010, the ratio of medical care-related expenditure and social welfare servicerelated expenditure over $\mathrm{NI}$ doubled and tripled, respectively, the ratio of pension-related expenditure over $\mathrm{NI}$ was increased almost five times. While the ratios of medical carerelated expenditure and social welfare 
service-related expenditure over NI did not rise in 1970s and 1980s when the economy grew relatively fast, the ratio of pension-related expenditure did rise in the period, and accelerated in 1990s and 2000s. Pension-related expenditure over $\mathrm{NI}$ has grown by $0.4 \%$ point on average since 1990 . One can suppose that the ratio of pension-related expenditure over $\mathrm{NI}$ may be related with the ratio of the elderly in the population, because pension benefit is mainly paid to the elderly. Figure 19 depicts the scatter diagram with the ratio of pension benefit over $\mathrm{NI}$ in the vertical axis and the demographic share of the elderly in the horizontal axis.6) Correlation coefficient between the share of the elderly and the ratio of pension related expenditure over $\mathrm{NI}$ is 0.98 .

\subsection{Medical care}

Total cost of the medical care in 2010 in Japan was 37.4 trillion yen, among which 20.7 trillion yen (55\% of the total cost) was for the elderly the share of whom in the population was $23 \%$ Figure 20 shows the change of the total cost of medical care and cost of the medical care for the elderly aged 75 and over. Although the total cost increases every year, the share of the cost for the elderly aged 75 and over in the total cost rose until 1999 and after that decreased. In the same period, the demographic share of the elderly aged 75 and over continued to increase as shown in Figure 18. On the contrary to the change of the cost share, demographic share accelerated its increase in 2000s.

Figure 20 also plots the ratio of the cost of the medical care over NI. The ratio of the total cost dearly shows upward tendency especially after 1990, whereas that for the elderly peaked in 1999, stayed in around 3\%level until 2008, and began to increase again after 2009. As in Figure 19, Figure 21 plots the scatter diagram with the ratio of cost of medical care over NI in the vertical axis and the demographic share of the elderly aged 75 and over in the horizontal axis. Correlation coefficient between two variables is 0.91 . However, the estimated relationship is not as strong as between pension and the share of the elderly.

6) Data in Figure 19 cover from 1970 because the pension system was established in 1960s. 
Figure 19. Pension benefit / NI and the Share of the Elderly

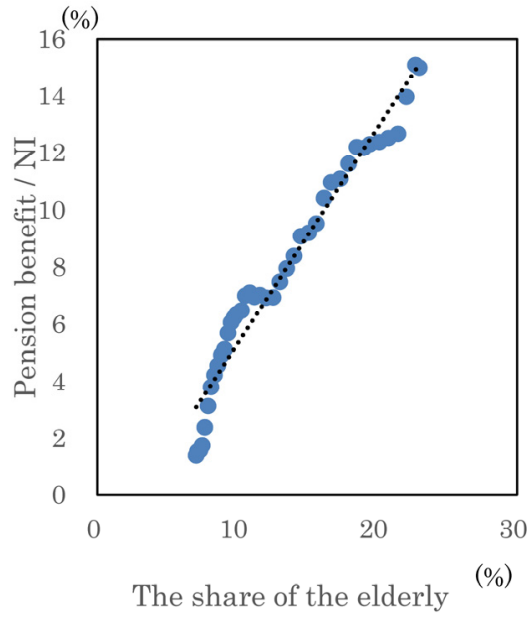

Source: Ministry of Health, Labour and Welfare Japan
Figure 20. Medical Expenses

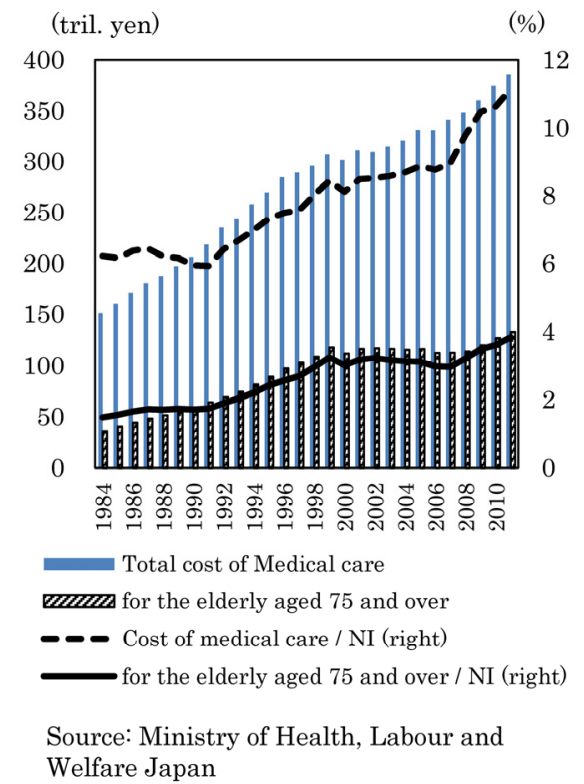

\subsection{Nursing care}

The increase in the demographic share of the late-stage elderly (75 and over) may also have strong relationship with nursing care. Figure 22 plots the changes of the costs of the nursing care. The cost has been increasing by on average 3.8 trillion yen a year, which is contrary to the stagnation of the medical cost for the late-stage elderly in Figure 20. The ratio of the nursing care cost over $\mathrm{NI}$ also continues to increase.

Figure 23 plots the scatter diagram with the ratio of cost of nursing care over $\mathrm{NI}$ in the vertical axis and the demographic share of the elderly aged 75 and over in the horizontal axis. Correlation coefficient between the ratio of cost of nursing care over $\mathrm{NI}$ and demographic share of the elderly aged 75 and over is 0.97 . 
Figure 21. Cost of Medical Care / NI and the Share of the Elderly (75 and over)

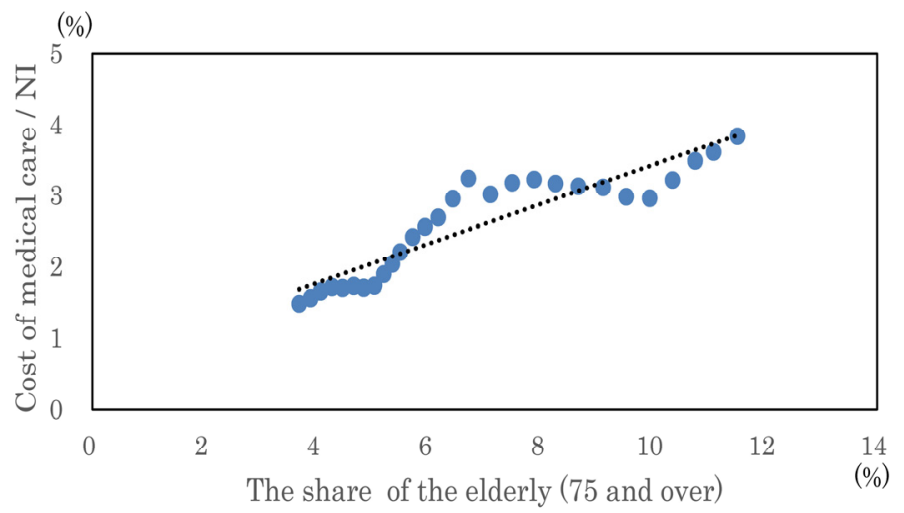

Figure 22. Nursing Care Cost

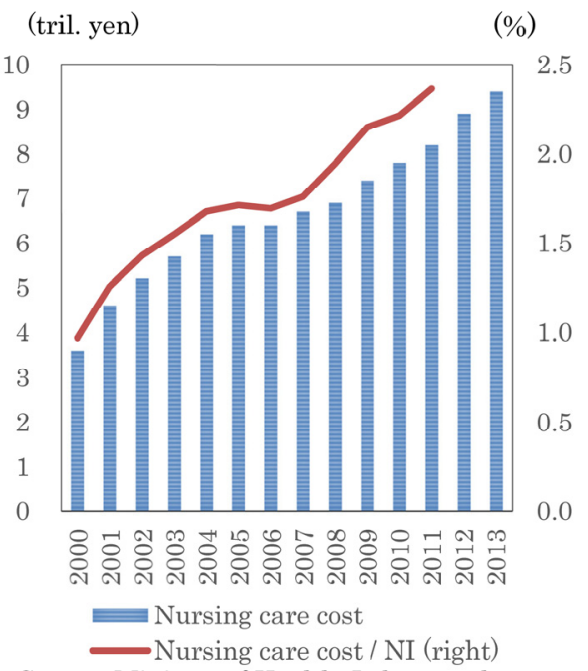

Source: Ministry of Health, Labour and Welfare Japan
Figure 23. Nursing Care Cost and the Share of the Elderly (75 and over)

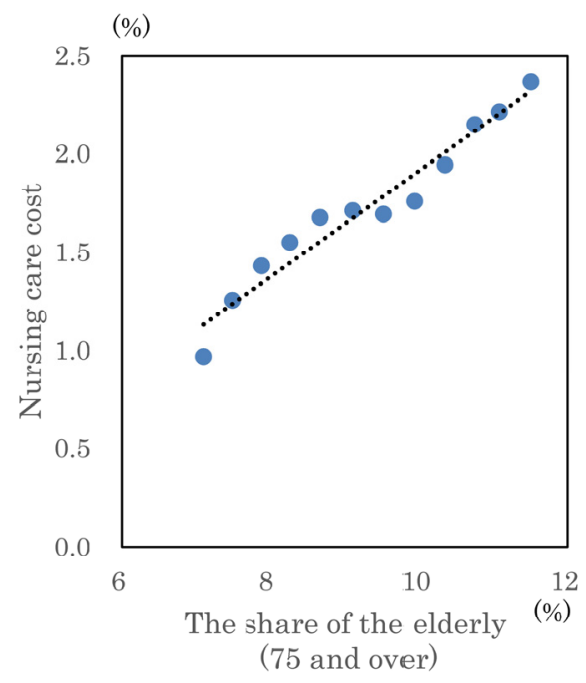

\section{Labor Force and Economic Growth}

We confirmed that the changes in the population structure of the economy, especially dedining birth rate and population aging, has had a significant impact on the financial condition of the Japanese government by increasing the social security-related expenditure. However, as seen in Figures 7 and 8, stagnant tax revenue had 
greater impact on the accumulated government bond. The stagnant tax revenue is attributable to the long-lasting recession, the lost decades. Then, how much impact did the population change have on the weakened economic growth?

Figure 24 plots the changes in the structure of the labor force by age group in 1963-2011. The labor force continued to increase until the late 1990s, and the proportion of the group of 60 years or older also went on increase gradually. We can see the change in the distribution through time, by comparing the age distributions of every 10 years. In 1970, the first baby boomers after World War II flew in the labor force, and they were about 20 year old. They are the biggest group in 1970 through 1990. A mass of one second baby boomers appears in 1990 and became distinguished in 2000 and 2010. In 2010, the first baby boomer generation faces the retirement, and the second baby boomers are leading the economy. Since the first baby boomers began to leave the work place, and to become recipients of social security, the cost of social security is expected to surge at a rate faster than ever expected.

Then, how important is the population change in the economic growth in J apan? Growth accounting may be one of the most intuitive ways to understand the impact of the population change on the economic growth. Figure 25 summarizes the results of the growth accounting of the Japanese economy from 1970 to 2010 with 5 year interval.7) The length of each bar means the contribution of each production factors to GDP growth. For example, GDP has grown at 5.2\% annual rate between 1975 and 1980, and the growth is attributable to the man-hours growth by $0.75 \%$ point, to labor quality and hours-worked growth by $0.88 \%$ point, to capital input growth by $1.2 \%$ point, and to the total factor productivity (TFP) growth by $2.4 \%$ point. In 1970 s and 80 s, Japanese economy grew on average at $4.5 \%$ annual rate, and the contribution of the number-of-workers growth was $0.4 \%$ point. The most important contributor of the growth in 1970s and 1980s was TFP growth which accounts for $40 \%$ of the GDP growth during the period.

The economy, then, speeded down its growth on average at $0.8 \%$ annual rate in 1990s and 2000s. The contributions of the number-of-workers growth to GDP

7) All the data and growth accounting are taken from Japan Industrial Productivity Database (http://www.rieti.go.jp/jp/database/I I P2013/index.html). To single out the effect of the slowdown of the number of workers, growth accounting is revised by the authors. 
Figure 24. Labour Force by Age Group

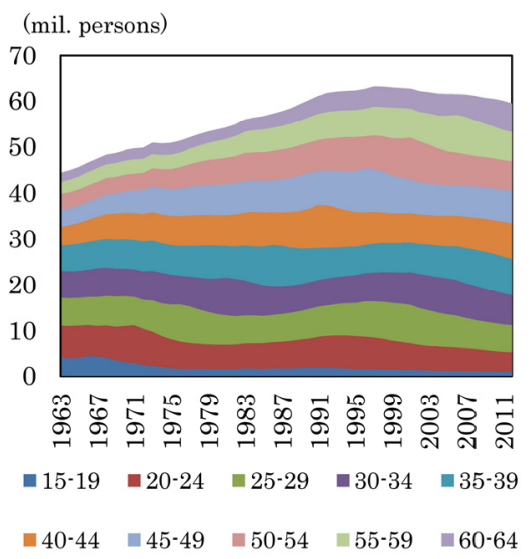

Source: Population Estimates, Ministry of internal affairs and communications Japan
Figure 25. Growth Accounting (Japan)

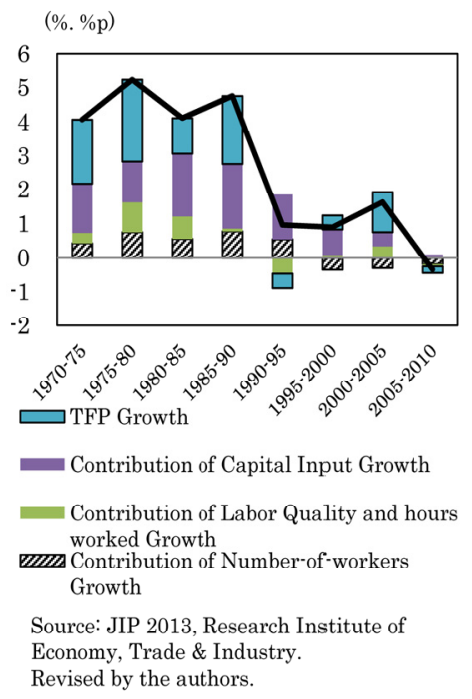

growth in 1990 s and 2000 s were $-0.07 \%$ point, and the most important contributor was TFP growth (0.2\% point). When comparing 1990 s and 2000 s with 1970 s and 1980s, GDP growth rate slowed down by $3.8 \%$ point, and number-of-workers growth slowed down by $0.45 \%$ point which accounts for $12 \%$ of the slow-down of GDP growth. Slow-down of TFP growth was $1.6 \%$ point ( $42 \%$ of the slow-down of GDP growth).

To measure the decrease of tax revenue caused by the slowed-down of man-hours growth, the relationship between GDP and tax revenue should be statistically proved. Figure 26 plots the scatter diagram with the tax revenue in the vertical axis and GDP in the horizontal axis, showing that the relationship is very stable and correlation coefficient between two variables is 0.99 .

In the previous paragraph, slow-down of number-of-workers growth negatively contributed to the economic growth by $0.45 \%$ of GDP growth in 1990 s and $2000 \mathrm{~s}$ compared with those in 1970s and 1980s. The economic growth slow-down must have negative impact on the tax revenue.

Hayashi and Prescott (2002) research the lost decade (1990s) of J apanese economy, conduding that decelerations of labor force growth and productivity growth are the main cause of the lost decade of the J apanese economy. 
Figure 26. Revenue of General Accounts-Taxes \& Stamp Duties and GDP (1965-1990)

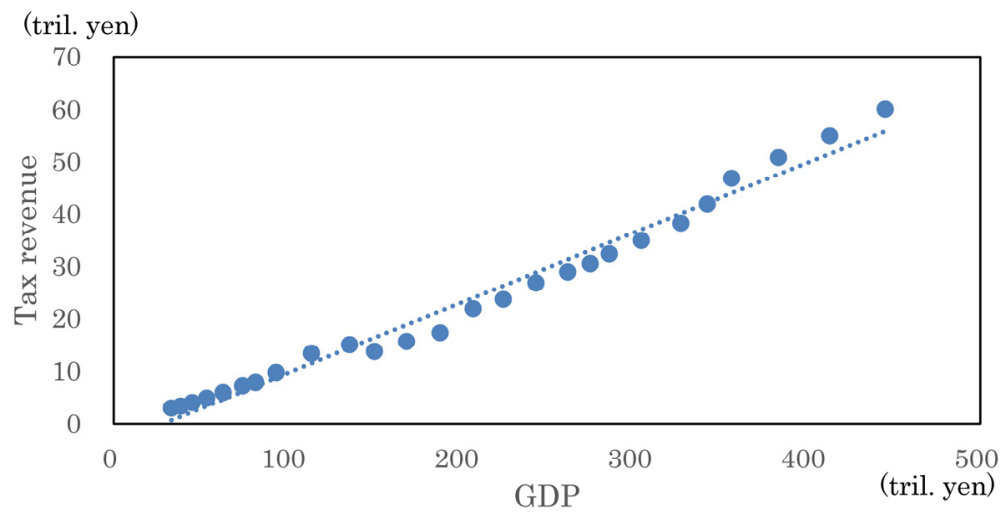

\section{The Long Run Korean Government's Fiscal Conditions}

In the previous sections we focus on the background of the deterioration of Japanese government financial status during the past 20 years. We can confirm that the negative impact of low birth rate and population aging is one of the main reasons for them. Specially, the population aging has been primary cause because it brings about lots of social security-related costs.

Now let's turn to the case of Korea. The share of population aged 65 years or older in Korea is $12.2 \%$ in 2013 , which is much lower than that of J apan, $24.1 \%$ in 2012. However, Korea is experiencing dramatic population aging as a result of reduced birth rate and increased longevity. It will not take so long time before the demographic structure of Korea looks like that of J apan. For instance, Korean fertility rate in 2010 is estimated 1.23, which is lower than that of J apan, 1.41 in 2012. This section discuss on the Korean population structure shortly, comparing with that of Japan, and evaluate the sustainability of Korean long-term fiscal policy through the Generation Accounting.

\section{The Korean Demographic Structure}

As said before, Korea is moving to an aged society very rapidly. According to the World Population Prospects by the United Nations, the old age dependency ra- 
tio, the share of the population of aged 65 and over the population aged between 15 and 64, of Korea is $15.2 \%$ in 2010, which is similar to that of J apan in 1985. However it is expected to rise to $22.1 \%$ in $2020,38.6 \%$ in 2030, $57.2 \%$ in 2040 , and $80.6 \%$ in 2060 . In 2029 , the Korean old age dependency ratio is expected to be same with that of J apan in 2010. Seeing Figure 27, the old age dependency ratio of Korea followed that of J apan with the time lag of 20 years before 2015. The time lag will be getting shorter after 2015. This can be checked by the comparison of fertility rate between the two countries. The fertility rate of Korea in 1990 (1.6) was al ready much lower than that of J apan 2.0 in 1970.

\section{Evaluating the Sustainability of Korean Long-term Fiscal Policy}

In this section, we will evaluate the sustainability of Korean long-term fiscal policy through the method of the Generational Accounting (GA). This method is used to evaluate long-term fiscal sustainability and fiscal burdens of current and future generations depending on long-term prospects.

Figure 27. Comparison of Old Age Dependency Ratio

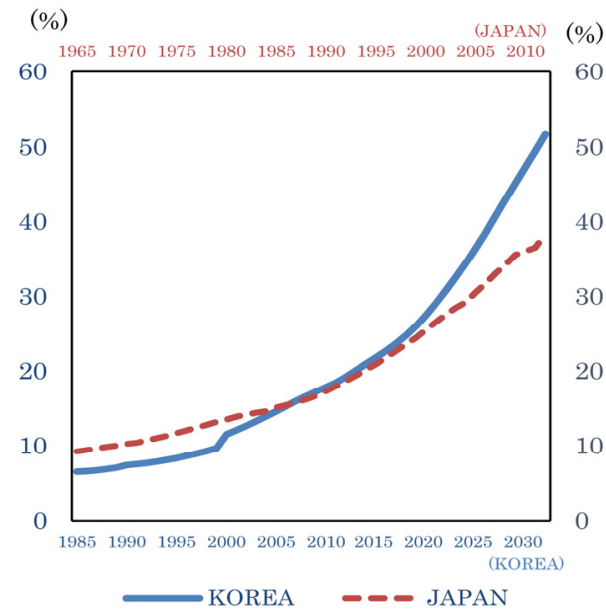

Sources: National Institute of Population and Social Security Research Japan, Statistics Korea
Figure28. Comparison of Fertility Rate

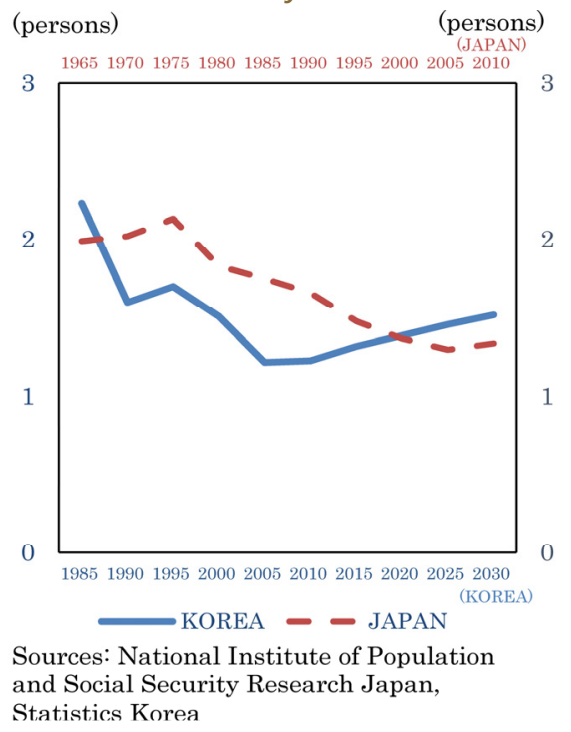




\subsection{Definition of the Generational Accounting (GA)}

The GA is a method of estimating prospective per capita lifetime net tax burdens that different cohort would face under existing fiscal policies. 'Prospective' means that fiscal burdens are evaluated over cohorts' remaining lifetimes; 'net tax' means that government transfers (such as social security benefits, unemployment benefits) are subtracted from taxes (such as consumption tax, contribution to national pension); and 'lifetime' indicates that future cash flows are actuarially discounted back to the present and aggregated into a summary measure of the fiscal burden in present value.8)

The basis of the GA method is presented by a simple government inter-temporal budget constraint. The sources of government's spending of current and future are government's current net wealth, the net tax of current living and future generations. The GA will be explained in detail by appendix.
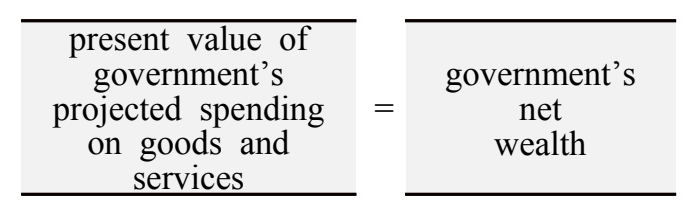
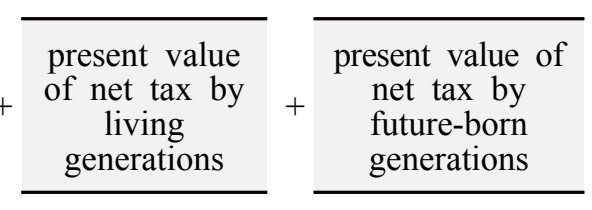

\subsection{Constructing the GA}

To construct the generational account, tax, transfer and demographic projections are needed. Projecting the tax and transfer of living generation requires the population projection in each year in which at least some member of living generation alive. We make use of long-term population projections by Korea National Statistics covering the period 2010-2060. After 2060, we assumed the population has no change.

The tax and transfer we cover are following things: (1) Related with social securities: Public Pension (National Pension, Pension for Civil Servants, Pension for Private School Employees), Medical Insurance, Employment I nsurance, Industrial

8) The definition of GA is from the New Pal grave Dictionary of Economics. 
Accident Compensation Insurance, Minimum Living Standards Security System, Basic Old-age Pension, Long-Term Care Insurance (2) Tax: Labor Income Tax, Consumption Tax, Tax on Asset-holding, Other Taxes, (3) Government Expenditure: Government (Central and local) Expenditure, Public Corporation Expenditure.

The current and future tax and transfer totals are distributed to each generation by age based on corresponding distributions in cross-section micro data. The micro data indude diverse Yearbooks, Survey of Household Finances and Living Conditions, etc.

In the case of Government Expenditure, we consider not only General Government Budget but also Public Corporation Expenditure. The total expenditure is distributed to each generation by age evenly. The allotted numbers on each generation are divided by population to gain the average expenditure of government and public corporations.

Next, to make present value cal culations in each of the cases, we should dedide on the appropriate discount rate. We use the discount rate for the real interest rate by the Long-term Projection by National Assembly Budget Office (2012). The sum of real growth rate (3\%) and inflation rate (2\%).

We regard measure of the government net weal th as net government capital income, induding net interest income and rents, divided by our assumed discount rate (5\%), following the method of Auerbach et al. (1991).

\subsection{Results and implications}

The Table 1 shows the generational accounts in Korea in total under the assumptions of discount rate (5.0\%) and population projection by Statistics Korea. The cohorts above 55 years report negative numbers, meaning that the amount of receive from the government is bigger than that of pay to it. In the case of future generation, the burden is estimated to amount about 396 million won on average in 2011 present value, which is 5.5 times bigger than that of the youngest aurrent generation burden 71 million won.

Looking at the social security-related components of generational accounts, we 
can find following things. All the current generations have a negative burden for National Pension Fund. Pension for Civil Servants, Pension for Private School Employees are also structured favorable to current generations. The degree of favor is different with aging. Specially, Medical Insurance, Long-term Care Insurance, dosely related with population aging, give more favor to the old age group. Even though there have been lots of efforts to reduce the burden of future generation, the cost related with population aging will become big risk factors for the long-term sustainability of Korean fiscal policy conditions.

\section{Conclusion}

This paper reviewed the impact of demographic change upon the sustainability of long-term fiscal policy. Firstly, we try to figure out what are the main causes of poor financial condition of Japanese government with the demographic point of view. Next, based on the fact that Korean demographic structure follows that of J apan, we evaluate the long-term sustainability of Korean fiscal policy through the forward looking measure, GA. Main results are as follows.

In the case of J apan, there has been a big increase in social security-related expenditure with a secular trend of population aging from early 1990s. I ncrease of social security-related expenditure was brought about by the surge of the welfare benefit and stagnated insurance premium revenue. Insurance premium revenue stagnated because national income did not grow enough during the period, whereas welfare benefit surged during the period because of low birth rate and population aging. Increased share of the elderly in the population pushed up especially pension benefit, medical care cost, and nursing care cost. Fertility rate has fallen down under 2 in mid-1970s, and demographic changes began and had a great impact on the government finance about 20 years later.

In the case of Korea, we check the long run sustainability of fiscal policy using the method of the forward looking measure GA. The following are main results; the cohorts above 55 years in Korea will receive more from the government than pay without any change in current system. In the case of future generation, the burden is estimated to amount about 449 million won on average in 2011 present 
value. In terms of the social security-related components, all the current generations have a benefit for the service of National Pension Fund, Pensions for Civil Servants and for Private School Employees. Specially, the items related with population aging, such as Medical I nsurance and Long-Term Care I nsurance give a big benefit to the old age group. The results show that we still have lots of things to do to contribute to the long-term sustainability of fiscal condition despite lots of efforts to reduce the burden of future generation we have ever made.

On the other hand, there is another area we should make efforts to improve for our long-term fiscal policy sustainability. That is, we should make efforts to increase the tax revenue. In J apan, 58\% of the financial deterioration since 1990 is attributable to the decrease of tax revenue Labor input growth turned negative in 1990s through 2000s, so that it negatively contributed to the economic growth, which brings about the decrease of tax revenue. Doi (2009), Shirakawa (2010), and Fukao (2012) condudes that under the reasonable assumption, it takes a 30\% point increase of the consumption tax or long-term reconstruction plan lasting at least for 100 years to restore the sustainability of the government finance of J apan. J apanese government has a plan to enhance the consumption tax up to 10\% in 2015.

Even if Korea has not entered the aged society, the speed of aging in Korea is much more rapid than any other country in the OECD. There are urgent needs to counteract preemptively to the population aging, realized soon in the near future. Demographic structure changes slowly but steadily. The past 20 years of Japan's experience give us a great example to our preparing for future policy operations. J apanese demographic change does have great impact on the macroeconomic performance, especially, the government finance through the social security-related expenditure. We should make consistent effort to restore the sustainability of the welfare scheme itself as well as government finance. However, unless population structure changes in a wide range, the impact of such effort will be limited. As shown by the case of J apan, the effect of the decreased tax revenue is greater than that of increased expenditure. This implies that policy for improving the tax revenue through economic growth is also very important for the sustainability of government finance. 


\section{Appendix: The Methodology of Generational Accounting*}

Generational Accounts are based on the government's inter-temporal budget constraint. The generations are defined as males and females (we use only total figures in the main text) by specific years of age. The net payment is the difference between government tax receipts of all types (such as consumption tax, contribution to national pension) and government transfer payments of all types (such as social security benefits, unemployment benefits). The sum of present value of the net payments of exiting generations and the present value of the net payments of future generations is equal to the present value of government consumption minus the government's net wealth.

The inter-temporal budget constraint can be formulated following equation.

$$
\sum_{s=0}^{D} N_{t, t-s}+\sum_{s=1}^{\infty} N_{t, t+s}=\sum_{s=t}^{\infty} G_{s} \Pi_{j=1}^{s} \frac{1}{\left(1+r_{j}\right)}-W_{t}^{g}
$$

$N_{t, k}$ represents the present value of remaining net payments of the generation born in year $\mathrm{k} . N_{t, t}$ is the value of net payments of youngest generation born in year $\mathrm{t} ; N_{t, t-D}$ is the value of net payments of oldest generation born in year t-D. The first term in the left hand side adds together the present value of the net payments of exiting generations, who are born in $t$ to born in $t-D$. The second term in the left hand side sums all the present value of net tax of future generations. The first term on right hand side represents the sum of government consumptions. The second one $\left(W_{t}^{g}\right)$ is the government's net weal th at timet. $r_{j}$ means the pretax rate of return in year $j$.

Equation (A-1) means that government consumption increase (or decrease) should be offset by the increase (or decrease) of net payments by aurrent or future generations.

The term $N_{t, k}$ is defined in equation (A-2):

$$
N_{t, k}=\sum_{s=\max (t, k)}^{k+D} \bar{T}_{s, k} P_{s, k} \Pi_{j=t+1}^{S} \frac{1}{\left(1+r_{j}\right)}
$$

\footnotetext{
* Based on Alan J. Auerbach, J agdeesh Gokhale, and L aurence J. Kotlikoff (1991).
} 
$\bar{T}_{s, k}$ stands for the projected average net payment to the government made in year sby a member of the generation born in year $k$. By a generation's average net payment in year swe mean the average across all members of the generation alive in year sof payments made. $P_{s, k}$ is the number of surviving members of the cohort in year $s$ who were born in year $k$. For generations who are born in year $k$, where $k>t$, the summation begins in year $k$. Regardless of the generation's year of birth, the discounting is al ways back to year $t$. That is the GA focuses on the current and future net payments.

Now let's make a net payment $\left(N_{t, k}\right)$ for current and future generations. Following the method of Auerbach et al. (1991), estimating the values of $N_{t, k} \mathrm{~s}$ requires four main ingredients: relative age profiles, budgetary data, budgetary and demographic projections. The projection of population by age and sex are available from the National Statistics Korea and the budgetary data are also can be acquired in the annual books and the National Statistics Korea.

However, the relative age profiles and some budgetary projections are not available in the published reports or National Statistics Korea. We have to construct the relative age profiles, which are the distributions, by age and sex, of as many of taxes and transfers as possible, allow us to apportion the total amount of each government expenditure and revenue to the proper cohort. For example, the relative age profile for Medical Insurance contribution in 2011 can be made following ways. Firstly, the total contribution data in 2011 can be acquired in the annual report. Secondly, as there is no direct data of contributions by age and sex, we make use of the information from the labor statistics about wages by age and sex. Distribute the total contribution to the each cohort. And then, to get the average amount, we divide the each cohort by the each responding national population from Population Census. The final result is the average amount of Medical I nsurance contribution of each cohort. Lastly, this average values are used to construct the relative profiles to specific age-sex category, 40-year-old male.

Let us denote the relative profiles $R_{a, i}^{m}\left(R_{a, i}^{f}\right)$ average value of the th payment or receipt made by (received by) an age a male (female) in 2011 divided by the average valued of the type i payment (receipt) made by 40-year-old males in 2011. Let $H_{i, t}$ denote the aggregate revenues (expenditures) of type $i$ received by (made 
by) the government in year $t$. Finally let $\bar{h}_{a, i, t}^{m} \bar{h}_{a, i, t}^{f}$ denote, respectively, the average values for males and females of payment (receipt) $i$ in year $t$. Then we have

$$
H_{i, t}=\bar{h}_{40, i, t}^{m} \sum_{j=0}^{D}\left[R_{j, i}^{m} P_{t, t-1}^{m}+R_{j, i}^{f} P_{t, t-j}^{f}\right]
$$

: Total payments (receipts) of type $i$ in year $t$ equals the average values of these payments (receipts) for 40-year-old males times the cross-product of the age-sex profile for payment (receipt) $i$ and the population by age and sex.

Equation (A-3) says that total payments (receipts) of type $i$ in year $t$ equals the average value of these payment (receipts) for 40-year-old men times the cross-product of the agesex profile for payment (receipt) $i$ and the population by age and sex. We use equation (A-3) to solve for $\bar{h}_{40, i, t}^{m}$, given $H_{i, t}$, relative profiles and populations. The values of the $\bar{h}_{a, i, s}^{m} \mathrm{~s}$ and , $\bar{h}_{a, i, s}^{f} a \neq 40, \mathrm{~s}>\mathrm{t}$ are obtained by multiplying $\bar{h}_{40, i, t}^{m}$ by $R_{a, t}^{m}$ and $R_{a, i}^{f}$ respectively.

After calculation the term $\bar{h}_{40, i, t}^{m}$, we can extend this to the figures $\bar{h}_{40, i, t+k}^{m}(k$ $>0$ ) with an assumed growth rate, for example from the Long-term Projection by National Assembly Budget Office. This new term is used to calculate future total payments (receipts) of type $i\left(H_{i, t+k}\right)$ in year $t+k$, with fixed relative profiles and corresponding population projection.

$$
H_{i, t+k}=\bar{h}_{40, i, t+k}^{m} \sum_{j=0}^{D}\left[R_{j, i}^{m} P_{t+k, t+k-j}^{m}+R_{j, i}^{f} P_{t+k, t+k-j}^{f}\right]
$$


Table A-1. Generational Accounts of Korea (unit: thousand won, base year: 2011)

\begin{tabular}{|c|c|c|c|c|c|c|c|c|c|c|c|c|c|c|c|c|c|c|}
\hline & Tadal & $\begin{array}{l}\text { Netiond } \\
\text { Pension }\end{array}$ & $\begin{array}{l}\text { Medcal } \\
\text { Insurance }\end{array}$ & $\begin{array}{l}\text { Long } \\
\text { Term } \\
\text { Care } \\
\text { Insurane }\end{array}$ & $\begin{array}{l}\text { Basic } \\
\text { Od-Age } \\
\text { Pension }\end{array}$ & $\begin{array}{l}\text { Pension } \\
\text { for Ovil } \\
\text { Servarts }\end{array}$ & $\begin{array}{l}\text { Pension for } \\
\text { Plivele } \\
\text { Schod } \\
\text { Employees }\end{array}$ & $\begin{array}{l}\text { Enploymert } \\
\text { Insurance }\end{array}$ & $\begin{array}{l}\text { Industial } \\
\text { Accidert } \\
\text { Compers- } \\
\text { dion } \\
\text { Insurenoe }\end{array}$ & $\begin{array}{l}\text { Mrimm } \\
\text { Living } \\
\text { Senderds } \\
\text { Seanily } \\
\text { Sydem }\end{array}$ & $\begin{array}{c}\text { Labor } \\
\text { Income } \\
\text { Tax }\end{array}$ & $\begin{array}{l}\text { Oher } \\
\text { Taxes }\end{array}$ & $\begin{array}{l}\text { Consumpion } \\
\text { Tax }\end{array}$ & $\begin{array}{c}\text { Capital } \\
\text { Inocme } \\
\text { Tax }\end{array}$ & \begin{tabular}{c|} 
Tex on \\
Asset \\
hoding
\end{tabular} & $\begin{array}{c}\text { Assed } \\
\text { trensec } \\
\text { tian tax }\end{array}$ & $\begin{array}{l}\text { Goverment } \\
\text { Expenditure }\end{array}$ & $\begin{array}{l}\text { Public } \\
\text { Corporation } \\
\text { Expendure }\end{array}$ \\
\hline o 5 & 71,315 & $-16,822$ & 2,942 & 191 & $-1,786$ & $-2,046$ & -499 & $-2,621$ & 2,121 & $-2,589$ & 4,773 & 14,642 & 39,600 & 18,198 & 4,707 & 10,480 & $-141,708$ & -476 \\
\hline $5 \sim 10$ & 71,435 & $-30,829$ & 3,765 & 101 & $-2,411$ & $-2,930$ & -689 & $-3,101$ & 2,566 & $-2,943$ & 5,725 & 17,040 & 47,078 & 18,928 & 5,932 & 13,171 & $-145,656$ & -489 \\
\hline 10 15 & 93,251 & $-22,104$ & 8,906 & 395 & $-2,163$ & $-2,047$ & -536 & $-3,565$ & 2,911 & $-2,830$ & 6,617 & 18,148 & 50,472 & 19,148 & 6,169 & 13,706 & $-138,272$ & -464 \\
\hline $15 \sim 20$ & 104,392 & $-23,811$ & 9,418 & 546 & $-2,281$ & $-1,930$ & -519 & $-4,080$ & 3,347 & $-2,603$ & 8,054 & 19,970 & 55,899 & 19,976 & 6,964 & 15,420 & $-134,608$ & -452 \\
\hline $20 \sim 25$ & 110,197 & $-27,191$ & 5,669 & 524 & $-2,740$ & $-2,410$ & -615 & $-4,501$ & 3,742 & $-2,263$ & 9,965 & 21,796 & 61,421 & 20,970 & 8,072 & 17,739 & $-131,899$ & -443 \\
\hline $25 \sim 30$ & 107,281 & $-27,596$ & $-3,909$ & 102 & $-3,474$ & $-3,250$ & -788 & $-3,986$ & 3,701 & $-2,403$ & 12,189 & 22,379 & 63,586 & 21,582 & 9,121 & 20,011 & $-127,918$ & -430 \\
\hline 30 35 & 112,429 & $-21,563$ & $-9,666$ & -202 & $-3,880$ & $-3,801$ & -915 & $-3,197$ & 3,451 & $-2,605$ & 15,034 & 21,947 & 63,818 & 22,333 & 9,898 & 21,771 & $-120,394$ & -404 \\
\hline $35 \sim 40$ & 105,587 & $-16,392$ & $-19,426$ & -840 & $-4,901$ & $-5,208$ & $-1,155$ & $-2,625$ & 3,129 & $-3,020$ & 15,828 & 20,884 & 62,383 & 22,824 & 10,618 & 23,489 & $-117,071$ & -393 \\
\hline $40 \sim 45$ & 97,020 & $-11,731$ & $-27,643$ & $-1,481$ & $-5,864$ & $-7,072$ & $-1,404$ & $-2,125$ & 2,743 & $-3,287$ & 16,758 & 19,222 & 59,990 & 23,241 & 11,041 & 24,635 & $-111,079$ & -373 \\
\hline $45 \sim 50$ & 71,609 & $-10,542$ & $-35,853$ & $-2,219$ & $-7,003$ & $-9,605$ & $-1,691$ & $-1,725$ & 2,274 & $-3,428$ & 15,277 & 16,644 & 51,492 & 22,408 & 11,062 & 24,526 & $-104,043$ & -349 \\
\hline 50 55 & 36,262 & $-12,500$ & $-42,544$ & $-2,916$ & $-8,149$ & $-12,447$ & $-1,929$ & $-1,243$ & 1,773 & $-3,480$ & 12,793 & 12,955 & 41,633 & 20,511 & 10,156 & 21,659 & $-95,368$ & -320 \\
\hline $55 \sim 60$ & $-2,741$ & $-19,459$ & $-46,922$ & $-3,425$ & $-9,272$ & $-15,663$ & $-2,141$ & -797 & 1,258 & $-3,475$ & 9,595 & 9,777 & 30,559 & 18,342 & 9,345 & 19,544 & $-85,361$ & -287 \\
\hline 60 65 & $-44,215$ & $-28,935$ & $-50,066$ & $-3,794$ & $-10,459$ & $-17,083$ & $-2,090$ & -146 & 518 & $-3,508$ & 5,320 & 6,820 & 19,950 & 15,179 & 7,982 & 16,102 & $-74,749$ & -251 \\
\hline $65 \sim 70$ & $-41,369$ & $-16,034$ & $-45,896$ & $-3,603$ & $-11,762$ & $-13,907$ & $-1,723$ & 0 & 0 & $-3,491$ & 4,291 & 4,851 & 13,893 & 12,737 & 6,406 & 12,870 & $-63,470$ & -213 \\
\hline 70 75 & $-34,422$ & $-7,160$ & $-38,574$ & $-2,822$ & $-9,474$ & $-9,724$ & -714 & 0 & 0 & $-3,277$ & 3,069 & 3,039 & 8,164 & 9,628 & 4,646 & 8,776 & $-52,295$ & -176 \\
\hline 75 80 & $-26,286$ & $-2,773$ & $-30,448$ & $-2,130$ & $-7,420$ & $-6,222$ & -186 & 0 & 0 & $-2,880$ & 2,179 & 1,856 & 5,571 & 7,171 & 3,118 & 5,877 & $-41,438$ & -139 \\
\hline $80 \sim 85$ & $-19,693$ & $-1,138$ & $-22,979$ & $-1,613$ & $-4,515$ & $-3,166$ & -204 & 0 & 0 & $-2,476$ & 1,364 & 1,049 & 4,209 & 4,767 & 1,813 & 3,196 & $-31,885$ & -107 \\
\hline $85 \sim 90$ & $-14,161$ & -856 & $-16,399$ & $-1,235$ & $-3,938$ & $-1,595$ & -315 & 0 & 0 & $-1,985$ & 997 & 841 & 3,053 & 3,408 & 1,386 & 2,477 & $-23,865$ & -80 \\
\hline $90 \sim$ & $-10,289$ & -578 & $-11,756$ & $-1,082$ & $-2,160$ & $-1,072$ & -140 & 0 & 0 & $-1,616$ & 645 & 573 & 2,164 & 2,293 & 826 & 1,613 & $-17,790$ & -60 \\
\hline future & 396,204 & & & & & & & & & & & & & & & & & \\
\hline
\end{tabular}




\section{$<$ References $>$}

Auerbach, Alan J. (2012), "Sodietal Aging: Implications for Fiscal Policy,"

Discussion Paper Series 2012-E-12, I MES, Bank of J apan.

Auerbach, Alan J., Jagdeesh Gokhale, and Laurence J. Kotlikoff (1991),

"Generational Accounts: A meaningful Alternative to Deficit Accounting,"

in D. Bradford ed., Tax policy and the economy, Cambridge, MIT Press,

Vol. 5 pp. 55-110.

Auerbach, Alan J., Laurence J. Kotlikoff, and Willi Leibfritz (1999),

"Generational Accounting around the World," National Bureau of

Economic Research Project, University of Chicago Press.

Auerbach, Alan J., Young J un Chun, and I lho Yoo (2005), "The Fiscal Burden

of Korean Reunification: A Generational Accounting Approach,"

FinanzArchiv: Public FinanceAnalysis, Vol. 61(1), pp. 62-97.

Auerbach, Alan J. and Young Jun Chun (2006), "Generational Accounting in

Korea," Journal of the Japanese and I nternational Economies, Vol. 20, No

2, pp. 234-68.

Aoki, Reiko (2012), "A Demographic Perspective on Japan's Lost Decades,"

Population and Development Review, Vol. 38, pp. 103-112.

Cabinet Office Japan (2013), "A Test Calculation about the Medium-and-long

Term Economic and Fiscal Policy," A material submitted to the Council on

Economic and Fiscal Policy.

Doi, Takero (2009), "After a Party of the Financial Dispatch - Fiscal and Tax re-

form," Vitalization of the Japanese Economy, the Role of the Market and Government, Nikkei I nc.

Felix, Alison and Kate Watkins (2013), "The Impact of an Aging U.S. Population on State Tax Revenues," Economic Review, Federal Reserve Bank of Kansas City.

Fukao, Mitshuhiro (2012), "J apanese Fiscal Deficit and its Sustainability," RIETI Discussion Paper Series 12-J-018.

Hayashi, Fumio and Edward C. Prescott (2002). "The 1990s in J apan: A Lost Decade," Review of Economic Dynamics, Vol. 5(1), pages 206-235. 
Keiichiro, Kobayashi (2013), "A Survey of Fiscal Sustainability and Economic Growth," RI ETI Discussion Paper Series 13-P-004.

Ki-Hong, Choi (2013), "The Generational Accounting of the National Pension and Measurement of I ntergenerational Equity," Korean Journal of Public Finance, Vol. 6(3), pp. 1-29.

Kotlikoff, Laurence J., and Scott Burns (2004), "The Coming Generational Storm: What You Need to Know about Americas Economic Future," MIT Press.

National Assembly Budget Office Korea (2012), “2012-2060 Long-term Economic Outlook and Fiscal Analysis."

Park, Hyung-soo and Seung Hyun Hong (2011), "A Study on the Fiscal I mpact of Demographic Change," Korea I nstitute of Public Finance.

Schick, Allen (2005), "Sustainable Budget Policy: Concept and Approaches," OECD Journal of Budgeting, Vol. 5 No. 1.

Shirakawa, Hiromichi (2010), "A Consideration of the Impact that World Financial and Economic Crisis has on J apanese Economy," Total Picture of the World Financial and Economic crisis-Causes, Influences, and Policy Responses, ed. Kazuo Ueda, Keio University Press.

Suzuki, Wataru, Minoru Masujima, Kosuke Shiraishi, and Akihiro Morishige (2012), "Intergenerational I nequality Caused by the Sodal Security System," ESRI Discussion Paper Series No.281.

Palgrave Macmillan, The New Palgrave Dictionary of Economics. Second Edition, 2008. 


\section{$<$ Abstract in Korean $>$}

\section{김영각*, 김명철**, 임성용}

본고는 인구구조 변화가 중장기 재정건전성과 재정정책의 지속가능성에 미치는 영향을 분석하였다. 우선 일본 재정상황 악화 원인을 인구구조의 변화에 초점을 맞추어 규명하였다. 다음으로 세대간 회계를 이용하여 우리나라의 인구구조 변화가 중장기 재정여건에 미칠 영향에 대해 살펴보았다. 일본은 1990년 이후 인구 고령화 등으로 사회보장 관련 지출이 크게 늘어나면서 재정상황이 크게 악화되었다. 아울러 경제활력 저하에 따른 세수기반 위축으로 정부의 재정수입도 크게 줄었다. 우리나라의 경우에도 과거 일본과 유사하게 빠른 속도로 고령화가 진행되면서 선제적 대응이 없으면 중장기 재정상황이 크게 악화될 가능성이 있다. 우리나라의 생산가능인구 대비 65세 이상 인구 비율인 고령인구부양비율이 약 20년의 차이를 두고 일본과 같이 급속히 오르고 있다. 세대간 회계를 적용하여 분석해 본 결과 이러한 고령화에 따른 사회복지지출 증가 등으로 우리나라의 중장기 재정건전성도 악화될 것으로 예상된다. 따라서 인구구조 변화에 따른 재정건전성 악화에 적극적으로 대처할 필요가 있다. 이와 함께 성장잠재력을 확충하여 세수기반의 안정을 도모하는 것도 중장기 재정건전성을 확보하는 데 매우 중요함을 확인하였다.

* 일본 專修대학교 부교수, ykim@isc.senshu-u.ac.jp

** 한국은행 통화정책국 정책분석팀 차장, kimmc@bok.or.kr

*** 한국은행 통화정책국 정책분석팀 조사역, imsy@bok.or.kr

연구내용은 집필자의 개인의견이며 한국은행의 공식견해와는 무관합니다. 따라서 본 논문의 내용을 보도 하거나 인용할 경우에는 집필자명을 반드시 명시하여 주시기 바랍니다. 